\title{
Design, synthesis, molecular modeling, and anti-HIV-1 integrase activity of a series of photoactivatable diketo acid-containing inhibitors as affinity probes
}

\author{
Mario Sechi $i^{a, *}$, Fabrizio Carta ${ }^{a}$, Luciano Sannia ${ }^{a}$, Roberto Dallocchio ${ }^{b}$, Alessandro Dessì $^{\mathrm{b}}$, \\ Rasha I. Al-Safi ${ }^{\mathrm{c}}$, Nouri Neamati ${ }^{\mathrm{c}, * *}$ \\ a Dipartimento Farmaco Chimico Tossicologico, Università di Sassari, Via Muroni 23/A, 07100 Sassari, Italy \\ b CNR-Istituto di Chimica Biomolecolare, Sassari, Trav. La Crucca 3, reg. Baldinca, 07040 Li Punti, Italy \\ c Department of Pharmacology and Pharmaceutical Sciences, University of Southern California, School of Pharmacy, \\ 1985 Zonal Avenue, Los Angeles, CA 90089, USA
}

\section{A R T I C L E I N F O}

\section{Article history:}

Received 16 August 2008

Received in revised form 6 December 2008

Accepted 11 December 2008

\section{Keywords:}

HIV-1 integrase inhibitors

Diketo acids

Photoaffinity labeling

Photoprobes

\begin{abstract}
A B S T R A C T
The diketo acid (DKA) class of HIV-1 integrase (IN) inhibitors is thought to function by chelating divalent metal ions on the enzyme catalytic site. However, differences in mutations conferring resistance to various DKA inhibitors suggest that multiple binding orientations may exist. In order to facilitate identification of DKA binding sites, a series of photoactivable analogues of two potent DKAs was prepared as novel photoaffinity probes. In cross-linking assays designed to measure disruption of substrate DNA binding, the photoprobes behaved similarly to a reference DKA inhibitor. Molecular modeling studies suggest that such photoprobes interact within the IN active site in a manner similar to that of the parent DKAs. Analogues Ia-c are novel photoaffinity ligands useful in clarifying the HIV-1 binding interactions of DKA inhibitors.
\end{abstract}

(c) 2009 Elsevier B.V. All rights reserved.

\section{Introduction}

HIV-1 integrase (IN) is an attractive and validated target for developing novel antiretroviral agents (Neamati, 2001; Anthony, 2004; Pommier et al., 2005). Because of its vital role in the viral replication cycle, with no human counterpart of the enzyme known, the addition of an IN inhibitor to existing components of antiretroviral therapy (Barbaro et al., 2005) is expected to improve the outcome of therapy by potential synergism (De Clercq, 2002, 2005), without exacerbating toxicity (Cohen, 2002; Little et al., 2002).

In the past several years, a plethora of compounds with diverse structural features has been reported as IN inhibitors (Cotelle, 2006; Neamati, 2002). Several of them inhibit both the viral enzyme and viral replication in cell-based assays, as well as in animal models (Pommier et al., 2005). Among all the reported inhibitors, the $\beta$-diketo acid (DKA) class of compounds has shown the most promising results (Hazuda et al., 2000; Pais and Burke, 2002; Pommier et al., 2005). After about 15 years of study, the DKA-based derivative, Raltegravir (MK-0518, Plate 1), has been approved by the US Food and Drug Administration (Rowley, 2008; Wang et al., 2007). It is believed that the DKA pharmacophoric motif could be

\footnotetext{
* Corresponding author. Tel.: +39 079228 753; fax: +39 079228720

** Corresponding author. Tel.: +1 323442 2341; fax: +1 3234421390 .

E-mail addresses: mario.sechi@uniss.it (M. Sechi), neamati@usc.edu (N. Neamati)
}

involved in a functional sequestration of one or both divalent metal ions that are critical cofactors at the enzyme catalytic site (Grobler et al., 2002; Pommier et al., 2005; Sechi et al., 2009). This would subsequently block the transition state of the IN-DNA complex (Espeseth et al., 2000). In this scenario it is of paramount importance to acquire information about the mode of action of DKAs that could then be useful in the design of new IN inhibitors.

Photoaffinity-labelling (PL) technology is emerging as a very useful tool for the identification and localization of proteins and their active sites in drug-discovery studies (Dormán and Prestwich, 2000; Fedan et al., 1984; Hatanaka and Sadakane, 2002; KotzybaHibert et al., 1995). This method is particularly useful for the identification of ligand-binding sites of target proteins and for the investigation of ligand-receptor interactions. The use of affinitylabeled inhibitors to covalently modify the site of interaction and subsequent analysis of the protein has been very effective in providing useful information about inhibitor binding for a multitude of therapeutic target proteins. The PL technology enables the direct probing of a target protein through a covalent bond that is photochemically introduced between a ligand and its specific receptor (Fig. 1). Thus, PL could be applied in two levels of drug discovery and development processes. At macro-level, the method is useful for the screening of early leads from the evaluation of affinity by cross-linking, to know which ligand preferentially binds to which protein. If the binding site analysis of a target protein is important for defining a particular pharmacophore, the PL will give the structural information of receptor binding domain at the micro-level. 


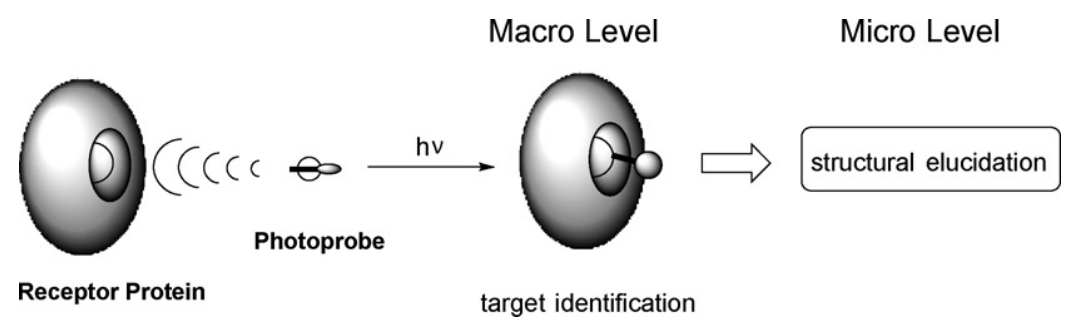

Fig. 1. The photoaffinity-labelling approach.<smiles>Cc1nnc(C(=O)NC(C)(C)c2nc(C(=O)NCc3ccc(F)cc3)c(O)c(=O)n2C)o1</smiles>

MK-0518 (Raltegravir)<smiles>O=C(O)/C=C(\O)C(=O)c1cccn1Cc1ccc(F)cc1</smiles>

L-731,988 (I)

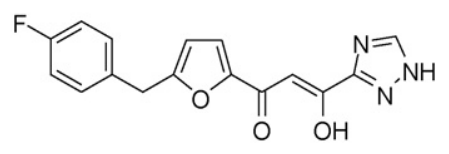

S-1360 (II)
Plate 1. Structure of the first HIV-1 IN inhibitor in therapy (MK-0518), and representative diketo acid-based compounds, L-731,988 (I), S-1360 (II), used in this study.

Such an approach can be used to obtain structural information detailing the association between the enzyme IN and inhibitors under development. In fact, application of PL to IN has elucidated a small number of inhibitor-binding sites at atomic resolution (AlMawsawi et al., 2006).

To facilitate identification of DKA binding sites, a series of photoactivable compounds, related to two potent DKA-based inhibitors, L-731,988 (I) (Hazuda et al., 2000) and S-1360 (II, Plate 1) (Yoshinaga et al., 2002; Billich, 2003), was prepared as photoaffinity probes (Fig. 2). The latter were designed by replacing the<smiles>CC(C)(Cc1ccc(F)cc1)C12CC3CCCC(C3)C1C2</smiles><smiles>[R]c1ccc(C(=O)C=C(O)c2nc[nH]n2)o1</smiles><smiles>CCc1ccc(N)cc1</smiles><smiles>CCc1c(F)c(F)c(N)c(F)c1F</smiles><smiles>NCCc1ccc(C(=O)c2ccccc2)cc1</smiles>

Fig. 2. Design of title compounds. para-fluoro-phenyl moieties of I and II with the three kinds of photophores, such as 4-azido-phenyl-, 4-azido-tetrafluorophenyl- and benzophenone, as photoreactive groups (Chehade and Spielmann, 2000; Dormán and Prestwich, 1994; Fleming, 1995). These photoprobes are expected to be useful tools for elucidation of the DKA binding mode and subsequent structure-based studies to design novel and selective IN inhibitors.

\section{Materials and methods}

\subsection{Experimental chemistry}

Anhydrous solvents and all reagents were purchased from Sigma-Aldrich, Merck or Carlo Erba. Anhydrous diethyl ether was obtained by distillation from $\mathrm{Na}$ /benzophenone under a nitrogen atmosphere. All reactions involving air- or moisture-sensitive compounds were performed under a nitrogen atmosphere using oven-dried glassware and syringes to transfer solutions. Melting points (mp) were determined using an electrothermal melting point or a Köfler apparatus and are uncorrected. Infrared (IR) spectra were recorded as thin films or nujol mulls on $\mathrm{NaCl}$ plates with a Perkin-Elmer 781 IR spectrophotometer and are expressed in $v$ $\left(\mathrm{cm}^{-1}\right)$. Nuclear magnetic resonance $\left({ }^{1} \mathrm{H}\right.$ NMR, ${ }^{13} \mathrm{C}$ NMR, NOE difference and NOESY) spectra were determined in $\mathrm{CDCl}_{3}$, DMSO- $d_{6}$ or $\mathrm{CDCl}_{3} / \mathrm{DMSO}-d_{6}$ (in $3 / 1$ ratio) and were recorded at $200 \mathrm{MHz}$ on a Varian XL-200. Chemical shifts ( $\delta$ scale) are reported in parts per million (ppm) downfield from tetramethylsilane (TMS) used as an internal standard. Splitting patterns are designated as follows: $s$, singlet; d, doublet; t, triplet; q, quadruplet; m, multiplet; brs, broad singlet; dd, double doublet. The assignment of exchangeable protons $(\mathrm{OH}$ and $\mathrm{NH})$ was confirmed by the addition of $\mathrm{D}_{2} \mathrm{O}$. Analytical thin-layer chromatography (TLC) was carried out on Merck silica gel F-254 plates. Flash chromatography purifications were performed on Merck Silica gel 60 (230-400 mesh ASTM) as the stationary phase. Elemental analyses were performed on a Perkin-Elmer 2400 spectrometer at Laboratorio di Microanalisi, Dipartimento di Chimica, Università di Sassari (Italy), and were within $\pm 0.4 \%$ of the theoretical values.

2.1.1. General procedure for the preparation of photoprobes [Ia-c]

A solution of the appropriate $\beta$-diketo ester 1a-c $(1 \mathrm{mmol})$ in $\mathrm{MeOH}(10 \mathrm{~mL})$ was treated with $2 \mathrm{~N} \mathrm{NaOH}$ (4.0 eq) and was stirred at r.t. for $5 \mathrm{~h}$. Then, the reaction mixture was diluted with water and acidified with $1 \mathrm{~N} \mathrm{HCl}$. The yellow precipitate formed was filtered off, washed with water and recrystallized from $\mathrm{H}_{2} \mathrm{O} / \mathrm{EtOH}$.

2.1.1.1. 4-[1-(4-Azidobenzyl)-1H-pyrrol-2-yl]-2-hydroxy-4-oxobut2-enoic acid [Ia]. Yield: 50\%; mp 171-173 ${ }^{\circ} \mathrm{C}$ dec. IR (nujol): $v$ $\left(\mathrm{cm}^{-1}\right) 2113$ ( $\mathrm{N}_{3}$ azide), 1719 ( $\mathrm{C}=\mathrm{O}$ acid), 1624 ( $\mathrm{C}=\mathrm{O}$ ketone). ${ }^{1} \mathrm{H}$ $\operatorname{NMR}\left(200 \mathrm{MHz}, \mathrm{CDCl}_{3}+\mathrm{DMSO}_{-} \mathrm{d}_{6}\right): \delta 7.21-6.89(\mathrm{~m}, 6 \mathrm{H}, \mathrm{Ar}-\mathrm{H}), 6.86$ (s, $1 \mathrm{H}, \mathrm{CH}=\mathrm{C}), 6.35-6.22\left(\mathrm{~m}, 1 \mathrm{H}, \mathrm{Ar}-\mathrm{H}\right.$, pyrrole), $5.61\left(\mathrm{~s}, 2 \mathrm{H}, \mathrm{CH}_{2}\right)$. MS: $m / z 312\left(\mathrm{M}^{+}\right)$. Anal. Calc. for $\left(\mathrm{C}_{15} \mathrm{H}_{12} \mathrm{~N}_{4} \mathrm{O}_{4}\right)$ : C, 57.69; $\mathrm{H}, 3.87$; N, 17.94. Found: C, 57.55; H, 3.79; N, 18.03. 
2.1.1.2. 4-[1-(4-Azido-2,3,5,6-tetrafluorobenzyl)-1H-pyrrol-2-yl]-2hydroxy-4-oxobut-2-enoic acid [Ib]. Yield: $18 \%$; mp $168-170^{\circ} \mathrm{C} \mathrm{dec}$. IR (nujol): $v\left(\mathrm{~cm}^{-1}\right) 2100$ ( $\mathrm{N}_{3}$ azide), 1707 ( $\mathrm{C}=\mathrm{O}$ acid), 1635 ( $\mathrm{C}=0$ ketone). ${ }^{1} \mathrm{H}$ NMR (200 MHz, $\left.\mathrm{CDCl}_{3}+\mathrm{DMSO}_{6}\right): \delta 7.70-7.25(\mathrm{~m}, 1 \mathrm{H}$, Ar-H, pyrrole), 7.05-6.75 (m, 1H, Ar-H, pyrrole), 6.44-6.13 (m, 1H, Ar-H, pyrrole), 5.81 (s, $1 \mathrm{H}, \mathrm{CH}=\mathrm{C}), 3.72\left(\mathrm{~s}, 2 \mathrm{H}, \mathrm{CH}_{2}\right)$. MS: $m / z 384$ $\left(\mathrm{M}^{+}\right)$. Anal. Calc. for $\left(\mathrm{C}_{15} \mathrm{H}_{8} \mathrm{~F}_{4} \mathrm{~N}_{4} \mathrm{O}_{4}\right)$ : C, 46.89; $\mathrm{H}, 2.10 ; \mathrm{N}, 14.58$. Found: $\mathrm{C}, 47.01 ; \mathrm{H}, 2.03 ; \mathrm{N}, 14.37$.

2.1.1.3. 4-[1-(4-Benzoylbenzyl)-1H-pyrrol-2-yl]-2-hydroxy-4oxobut-2-enoic acid [Ic]. Yield: 17\%; mp 242-244 ${ }^{\circ} \mathrm{C}$ dec. IR (nujol): $v\left(\mathrm{~cm}^{-1}\right) 1721$ ( $\mathrm{C}=\mathrm{O}$ acid), 1619 ( $\mathrm{C}=\mathrm{O}$ ketone). ${ }^{1} \mathrm{H}$ NMR $\left(200 \mathrm{MHz}, \mathrm{CDCl}_{3}\right): \delta 7.82-7.72(\mathrm{~m}, 3 \mathrm{H}, \mathrm{Ar}-\mathrm{H}), 7.60-7.40(\mathrm{~m}, 4 \mathrm{H}$, Ar-H), 7.24-7.09 (m, 4H, Ar-H), $6.93(\mathrm{~s}, 1 \mathrm{H}, \mathrm{CH}=\mathrm{C}), 6.36(\mathrm{~m}$, $1 \mathrm{H}, \mathrm{Ar}-\mathrm{H}), 5.71\left(\mathrm{~s}, 2 \mathrm{H}, \mathrm{CH}_{2}\right)$. MS: $m / z 375\left(\mathrm{M}^{+}\right)$. Anal. Calc. for $\left(\mathrm{C}_{22} \mathrm{H}_{17} \mathrm{NO}_{5}\right)$ : C, 70.39; $\mathrm{H}, 4.56 ; \mathrm{N}, 3.73$. Found: $\mathrm{C}, 70.57 ; \mathrm{H}, 4.48 ; \mathrm{N}$, 3.67.

\subsubsection{General procedure for the preparation of $\beta$-diketo esters [2a-c]}

To a suspension of $60 \% \mathrm{NaH}$ in mineral oil ( $5.0 \mathrm{mmol})$ in dry $\mathrm{Et}_{2} \mathrm{O}$ $(10 \mathrm{~mL})$ the corresponding ketone $\mathbf{1 a}-\mathbf{c}(1.7 \mathrm{mmol})$ was added and the reaction mixture was stirred under a nitrogen atmosphere at room temperature (r.t.) for $15 \mathrm{~min}$. Then, dimethyloxalate $(2.0 \mathrm{eq})$ was added and the reaction was stirred at r.t. for $3.5 \mathrm{~h}$ and at $50^{\circ} \mathrm{C}$ for $12 \mathrm{~h}$. Finally, the reaction was quenched with water and acidified with $2 \mathrm{~N} \mathrm{HCl}$ to afford a brown yellow precipitate.

2.1.2.1. Methyl 4-[1-(4-azidobenzyl)-1H-pyrrol-2-yl]-2-hydroxy-4oxobut-2-enoate [2a]. Yield: $67 \%$; mp $112-114{ }^{\circ} \mathrm{C} \mathrm{dec}$. IR (nujol): $v$ $\left(\mathrm{cm}^{-1}\right) 2113$ ( $\mathrm{N}_{3}$ azide), 1727 ( $\mathrm{C}=\mathrm{O}$ ester), 1624 ( $\mathrm{C}=\mathrm{O}$ ketone). ${ }^{1} \mathrm{H}$ NMR (200 MHz, $\left.\mathrm{CDCl}_{3}\right): \delta 14.50$ (brs, $1 \mathrm{H}$, enol), 7.20-6.90 (m, 6H, $\mathrm{Ar}-\mathrm{H}$, benzyl and pyrrole), $6.84(\mathrm{~s}, 1 \mathrm{H}, \mathrm{CH}=\mathrm{C}), 6.35-6.22(\mathrm{~m}, 1 \mathrm{H}$, Ar-H, pyrrole), $5.60\left(\mathrm{~s}, 2 \mathrm{H}, \mathrm{CH}_{2}\right)$. MS: $m / z 326\left(\mathrm{M}^{+}\right)$. Anal. Calc. for $\left(\mathrm{C}_{16} \mathrm{H}_{14} \mathrm{~N}_{4} \mathrm{O}_{4}\right)$ : C, 58.89; H, 4.32; N, 17.17. Found: C, 59.04; H, 4.23; $\mathrm{N}, 16.93$.

2.1.2.2. Methyl 4-[1-(4-azido-2,3,5,6-tetrafluorobenzyl)-1H-pyrrol2-yl]-2-hydroxy-4-oxobut-2-enoate [2b]. Yield: 20\%; mp 108-110 ${ }^{\circ} \mathrm{C}$ dec. IR (nujol): $v\left(\mathrm{~cm}^{-1}\right) 2106$ ( $\mathrm{N}_{3}$ azide), 1746 ( $\mathrm{C}=\mathrm{O}$ ester), 1638 ( $\mathrm{C}=\mathrm{O}$ ketone). ${ }^{1} \mathrm{H}$ NMR $\left(200 \mathrm{MHz}, \mathrm{CDCl}_{3}\right): \delta 14.44$ (brs, $1 \mathrm{H}$, enol), 7.16-7.10 (m, 1H, Ar-H, pyrrole), 7.00-6.94 (m, 1H, Ar-H, pyrrole), $6.84(\mathrm{~s}, 1 \mathrm{H}, \mathrm{CH}=\mathrm{C}), 6.31-6.23(\mathrm{~m}, 1 \mathrm{H}, \mathrm{Ar}-\mathrm{H}$, pyrrole), $5.79(\mathrm{~s}$, $\left.2 \mathrm{H}, \mathrm{CH}_{2}\right), 3.92\left(\mathrm{~s}, 3 \mathrm{H}, \mathrm{CH}_{3}\right)$. MS: $m / z 398\left(\mathrm{M}^{+}\right)$. Anal. Calc. for $\left(\mathrm{C}_{16} \mathrm{H}_{10} \mathrm{~F}_{4} \mathrm{~N}_{4} \mathrm{O}_{4}\right)$ : C, 48.25; $\mathrm{H}, 2.53 ; \mathrm{N}, 14.07$. Found: $\mathrm{C}, 47.85 ; \mathrm{H}$, $2.69 ; \mathrm{N}, 14.43$.

2.1.2.3. Methyl 4-[1-(4-benzoylbenzyl)-1H-pyrrol-2-yl]-2-hydroxy4-oxobut-2-enoate [2c]. Yield: $20 \%$; mp $138-140^{\circ} \mathrm{C} \mathrm{dec}$. IR (nujol): $v\left(\mathrm{~cm}^{-1}\right) 1731$ ( $\mathrm{C}=\mathrm{O}$ ester $), 1640$ ( $\mathrm{C}=\mathrm{O}$ ketone). ${ }^{1} \mathrm{H}$ NMR $(200 \mathrm{MHz}$, $\left.\mathrm{CDCl}_{3}\right): \delta 14.47$ (brs, $1 \mathrm{H}, \mathrm{OH}$, exchange with $\left.\mathrm{D}_{2} \mathrm{O}\right), 7.83-7.65(\mathrm{~m}$, 3H, Ar-H), 7.62-7.41 (m, 4H, Ar-H), 7.22-7.05 (m, 4H, Ar-H), 6.86 (s, $1 \mathrm{H}, \mathrm{CH}=\mathrm{C}), 6.39-6.30\left(\mathrm{~m}, 1 \mathrm{H}, \mathrm{Ar}-\mathrm{H}\right.$, pyrrole), $5.73\left(\mathrm{~s}, 2 \mathrm{H}, \mathrm{CH}_{2}\right)$, $3.91\left(\mathrm{~s}, 3 \mathrm{H}, \mathrm{OCH}_{3}\right)$. MS: $\mathrm{m} / z 389\left(\mathrm{M}^{+}\right)$. Anal. Calc. for $\left(\mathrm{C}_{23} \mathrm{H}_{19} \mathrm{NO}_{5}\right)$ : C, 70.94; H, 4.92; N, 3.60. Found: C, 71.23; H, 4.83; N, 3.49.

\subsubsection{General procedure for the preparation of}

\section{1-[1-(4-alkyl)-1H-pyrrol-2-yl]ethanones [1a-c]}

2-Acetylpyrrole 4 ( $2.83 \mathrm{mmol}$ ) was added to a suspension of $\mathrm{KOH}$ (4.0 eq) in dry DMSO $(20 \mathrm{~mL})$ and the reaction mixture was stirred at r.t. for $45 \mathrm{~min}$. Then, the appropriate benzyl bromide $\mathbf{5 a - c}$ ( $2.0 \mathrm{eq})$ was added, and the reaction was stirred for $2 \mathrm{~h}$ at r.t. The reaction was quenched with water and extracted with diethyl ether. The combined organic layers were dried over sodium sulfate, filtered and concentrated in vacuo to give a yellow oil $(\mathbf{1 a}, \mathbf{b})$ or a yellow solid (1c) that was purified by silica gel column chromatography (eluting with petrol ether/ethyl acetate $9 / 1$ for $(\mathbf{1} \mathbf{a}, \mathbf{b})$ or with an increasing amount of petrol ether/ethyl acetate from $8.5 / 1.5$ to $8 / 2$ for (1c) to afford a pale yellow oil (1a,b) or a yellow solid (1c), respectively.

2.1.3.1. 1-[1-(4-Azidobenzyl)-1H-pyrrol-2-yl]ethanone [1a]. Yield: 80\%; oil at r.t. IR (nujol): $v\left(\mathrm{~cm}^{-1}\right) 2108\left(\mathrm{~N}_{3}\right.$ azide), $1660(\mathrm{C}=\mathrm{O}$ ketone). ${ }^{1} \mathrm{H}$ NMR $\left(200 \mathrm{MHz}, \mathrm{CDCl}_{3}\right): \delta 7.11(\mathrm{~d}, 2 \mathrm{H}, \mathrm{Ar}-\mathrm{H}), 7.05-6.86$ ( $\mathrm{m}, 4 \mathrm{H}, \mathrm{Ar}-\mathrm{H}$, benzyl and pyrrole), 6.25-6.15 ( $\mathrm{m}, 1 \mathrm{H}, \mathrm{Ar}-\mathrm{H}$, pyrrole), $5.53\left(\mathrm{~s}, 2 \mathrm{H}, \mathrm{CH}_{2}\right), 2.41\left(\mathrm{~s}, 3 \mathrm{H}, \mathrm{CH}_{3}\right)$. MS: $m / z 240\left(\mathrm{M}^{+}\right)$.

2.1.3.2. 1-[1-(4-Azido-2,3,5,6-tetrafluorobenzyl)-1H-pyrrol-2yl]ethanone [1b]. Yield: 37\%; oil at r.t. IR (nujol): $v\left(\mathrm{~cm}^{-1}\right)$ $2109\left(\mathrm{~N}_{3}\right.$ azide), 1625 ( $\mathrm{C}=0$ ketone). ${ }^{1} \mathrm{H}$ NMR $\left(200 \mathrm{MHz}, \mathrm{CDCl}_{3}\right): \delta$ 7.02-6.94 (m, 1H, Ar-H, pyrrole), 6.87-6.81 (m, $1 \mathrm{H}, \mathrm{Ar}-\mathrm{H}$, pyrrole), 6.22-6.12 (m, 1H, Ar-H, pyrrole), $5.73\left(\mathrm{~s}, 2 \mathrm{H}, \mathrm{CH}_{2}\right), 2.44(2,3 \mathrm{H}$, $\left.\mathrm{CH}_{3}\right)$. MS: $m / z 312\left(\mathrm{M}^{+}\right)$.

2.1.3.3. 1-[1-(4-Benzoylbenzyl)-1H-pyrrol-2-yl]ethanone

[1c]. Yield: $45 \%$; $86-88^{\circ} \mathrm{C} \mathrm{dec}$. IR (nujol): $v\left(\mathrm{~cm}^{-1}\right) 1660$ ( $\mathrm{C}=0$ ketone). ${ }^{1} \mathrm{H}$ NMR $\left(200 \mathrm{MHz}, \mathrm{CDCl}_{3}\right): \delta 7.83-7.71(\mathrm{~m}, 3 \mathrm{H}, \mathrm{Ar}-\mathrm{H}), 7.60-7.54$ (m, 2H, Ar-H), 7.52-7.41 (m, 2H, Ar-H), 7.20-7.16 (m, 1H, Ar-H), 7.15-7.12 (m, 1H, Ar-H), 7.08-7.02 (m, 1H, Ar-H), 7.08-6.92 (m, 1H, $\mathrm{Ar}-\mathrm{H}), 6.24$ (dd, $1 \mathrm{H}, \mathrm{Ar}-\mathrm{H}), 5.66\left(\mathrm{~s}, 2 \mathrm{H}, \mathrm{CH}_{2}\right), 2.42\left(\mathrm{~s}, 3 \mathrm{H}, \mathrm{CH}_{3}\right) . \mathrm{MS}$ : $\mathrm{m} / \mathrm{z} 303\left(\mathrm{M}^{+}\right)$.

\subsubsection{Synthesis of 1-(1H-pyrrol-2-yl)ethanone [4] (Sechi et al., 2006)}

A solution of 2-acetylfuran $3(45.0 \mathrm{mmol})$ and $30 \%$ aqueous $\mathrm{NH}_{3}$ (19.0 eq) in EtOH $(30 \mathrm{~mL})$ was heated into a sealed tube at $160^{\circ} \mathrm{C}$ for $12 \mathrm{~h}$. Then, the reaction mixture was cooled to r.t., filtered and the filtrate was concentrated in vacuo to give a brown solid. The latter was purified by silica gel column chromatography eluting with petroleum $\mathrm{Et}_{2} \mathrm{O} /$ ethyl acetate 8/2 to afford a yellow solid that was crystallized from $\mathrm{H}_{2} \mathrm{O} / \mathrm{EtOH}$. Yield: $75 \% ; 88-89{ }^{\circ} \mathrm{C}$ (Lit. $88-89^{\circ} \mathrm{C}$ ) dec. IR (nujol): $v\left(\mathrm{~cm}^{-1}\right) 3260(\mathrm{NH}), 1640$ (ketone). ${ }^{1} \mathrm{H}$ NMR $\left(200 \mathrm{MHz}, \mathrm{CDCl}_{3}\right): \delta 10.10$ (brs, $\left.1 \mathrm{H}, \mathrm{NH}\right), 7.06-7.04(\mathrm{~m}, 1 \mathrm{H}$, Ar-H), 6.93-6.91 (m, 1H, Ar-H), 6.28-6.26 (m, 1H, Ar-H), 2.45 (s, $\left.3 \mathrm{H}, \mathrm{COCH}_{3}\right)$. MS: $m / z 109\left(\mathrm{M}^{+}\right)$

\subsubsection{Synthesis of 1-azido-4-(bromomethyl)benzene [5a]}

A $1 \mathrm{M}$ solution of $\mathrm{PBr}_{3}$ in $\mathrm{DCM}(2.41 \mathrm{mmol})$ was added dropwise with a syringe to a solution of $p$-azido-benzylalcohol 7 (6.03 $\mathrm{mmol})$ in dry DCM $(18 \mathrm{~mL})$ at $0-5^{\circ} \mathrm{C}$ under a nitrogen atmosphere. The reaction mixture was stirred at r.t. for $3.5 \mathrm{~h}$ and then quenched with a mixture of 2-propanol $(7.0 \mathrm{~mL})$ in DCM $(33.0 \mathrm{~mL})$, followed by addition of $1 \mathrm{M} \mathrm{NaHCO}_{3}(40 \mathrm{~mL})$. The reaction mixture was extracted with DCM, and the combined organic layers were dried over sodium sulfate, filtered and the solvent was evaporated in vacuo to give a yellow oil that was purified by silica gel column chromatography eluting with petroleum ether to afford a yellow oil. Yield: 75\%; oil at r.t. IR (nujol): $v\left(\mathrm{~cm}^{-1}\right) 2108$ ( $\mathrm{N}_{3}$ azide), 1600 $(\mathrm{C}=\mathrm{C}, \mathrm{Ar}-\mathrm{C}) .{ }^{1} \mathrm{H}$ NMR $\left(200 \mathrm{MHz}, \mathrm{CDCl}_{3}\right): \delta 7.37(\mathrm{~d}, 2 \mathrm{H}, \mathrm{Ar}-\mathrm{H}), 6.99$ (d, 2H, Ar-H), $4.48\left(\mathrm{~s}, 2 \mathrm{H}, \mathrm{CH}_{2}\right)$. MS: $m / z 212\left(\mathrm{M}^{+}\right)$.

\subsubsection{Synthesis of (4-azidobenzyl)alcohol [7] (Griffin, 1996)}

A solution of sodium nitrite $(30.5 \mathrm{mmol})$ was added portionwise to a solution of $p$-aminobenzylalcohol $6(20.3 \mathrm{mmol})$ in $5 \mathrm{~N}$ $\mathrm{HCl}(38 \mathrm{~mL})$ at $0^{\circ} \mathrm{C}$ and then $\mathrm{NaN}_{3}(81.2 \mathrm{mmol})$ was added slowly. The reaction mixture was stirred at $0{ }^{\circ} \mathrm{C}$ for $1 \mathrm{~h}$, then quenched with ice and adjusted to $\mathrm{pH} 8$ with $\mathrm{NaHCO}_{3}$. The mixture was extracted with ethyl acetate and the combined organic layers were dried over sodium sulfate, filtered and the solvent was removed in vacuo to give a yellow oil that was triturated with petroleum ether to afford a pale yellow solid. Yield: $92 \%$; mp $32-34{ }^{\circ} \mathrm{C}$ dec. (Lit. $31-33^{\circ} \mathrm{C}$.) IR (nujol): $v\left(\mathrm{~cm}^{-1}\right) 2106\left(\mathrm{~N}_{3}\right.$ azide), $1600(\mathrm{C}=\mathrm{C} \mathrm{C}-\mathrm{Ar}) .{ }^{1} \mathrm{H}$ NMR 
$\left(200 \mathrm{MHz}, \mathrm{CDCl}_{3}\right): \delta 7.35(\mathrm{~d}, 2 \mathrm{H}, \mathrm{Ar}-\mathrm{H}), 7.02(\mathrm{~d}, 2 \mathrm{H}, \mathrm{Ar}-\mathrm{H}), 4.67(\mathrm{~s}$, $\left.2 \mathrm{H}, \mathrm{CH}_{2}\right)$. MS: $m / z 149\left(\mathrm{M}^{+}\right)$.

\subsubsection{Synthesis of \\ 1-azido-4-(bromomethyl)-2,3,5,6-tetrafluorobenzene [5b] (Lei and Atkinson, 2000)}

A $1 \mathrm{M}$ solution of $\mathrm{PBr}_{3}$ in $\mathrm{DCM}(4.52 \mathrm{~mL}, 4.52 \mathrm{mmol})$ was added dropwise with a syringe to a solution of $\mathbf{1 1}(4.52 \mathrm{mmol})$ in dry DCM $(16 \mathrm{~mL})$ under a nitrogen atmosphere at $0-5^{\circ} \mathrm{C}$. The reaction mixture was stirred at r.t. for $4.5 \mathrm{~h}$ and quenched with a solution of 2-propanol $(20 \mathrm{~mL})$ in DCM $(63 \mathrm{~mL})$ followed by the addition of a $1 \mathrm{M}$ aqueous solution of $\mathrm{NaHCO}_{3}(82 \mathrm{~mL})$. The mixture was extracted with DCM and the combined organic layers were dried over sodium sulfate, filtered and the solvent was removed in vacuo to give a yellow solid that was purified by silica gel column chromatography eluting with petroleum ether/ethyl acetate 9/1 to afford a pale yellow solid. Yield: $55 \%$; mp $55-57^{\circ} \mathrm{C} \mathrm{dec}$. (Lit. 53-55 ${ }^{\circ} \mathrm{C}$.) IR (nujol): $v\left(\mathrm{~cm}^{-1}\right) 2110\left(\mathrm{~N}_{3}\right.$ azide). ${ }^{1} \mathrm{H} \mathrm{NMR}(200 \mathrm{MHz}$, $\left.\mathrm{CDCl}_{3}\right): \delta 4.50\left(\mathrm{~s}, 2 \mathrm{H}, \mathrm{CH}_{2}\right)$. MS: $m / z 284\left(\mathrm{M}^{+}\right)$.

\subsubsection{Synthesis of 4-azido-2,3,5,6-tetrafluorobenzylalcohol [11]} (Keana and Xiong Cai, 1990)

A solution of $\left(\mathrm{CH}_{3}\right)_{2} \mathrm{NH} \cdot \mathrm{BH}_{3}(1.2 \mathrm{eq})$ in acetic acid $(25 \mathrm{~mL})$ was added to a solution of $\mathbf{9}(13.7 \mathrm{mmol})$ in acetic acid $(20 \mathrm{~mL})$ and the reaction mixture was stirred at $60^{\circ} \mathrm{C}$ for $1 \mathrm{~h}$. Then, the reaction was quenched with water and extracted with chloroform and the combined organic layers were washed with a $5 \%$ aqueous solution of $\mathrm{Na}_{2} \mathrm{CO}_{3}$, dried over sodium sulfate, filtered and the solvent was removed in vacuo to give a white solid. Yield: $88 \%$; $\mathrm{mp} 80-82{ }^{\circ} \mathrm{C}$ dec. (Lit. $67-68^{\circ} \mathrm{C}$.) IR (nujol): $v\left(\mathrm{~cm}^{-1}\right) 2108\left(\mathrm{~N}_{3}\right.$ azide). ${ }^{1} \mathrm{H}$ NMR $\left(200 \mathrm{MHz}, \mathrm{CDCl}_{3}\right): \delta 4.79\left(\mathrm{~s}, 2 \mathrm{H}, \mathrm{CH}_{2}\right)$. MS: $m / z 221\left(\mathrm{M}^{+}\right)$.

\subsubsection{Synthesis of 4-azido-2,3,5,6-tetrafluorobenzaldehyde [9]}

(Keana and Xiong Cai, 1990)

$\mathrm{NaN}_{3}$ (1.1 eq) was added to a solution of pentafluorobenzaldehyde $8(25.5 \mathrm{mmol})$ in acetone $(48 \mathrm{~mL})$ and water $(18 \mathrm{~mL})$. The reaction mixture was stirred at reflux for $1 \mathrm{~h}$. Then, the reaction was cooled down to r.t., water $(60 \mathrm{~mL})$ was added and it was extracted with diethyl ether. The combined organic layers were dried over sodium sulfate, filtered and the solvent was removed in vacuo to give a mixture of para and ortho isomers that were separated by silica gel column chromatography eluting with petroleum ether/ethyl acetate 9.5/0.5.

2.1.9.1. 4-Azido-2,3,5,6-tetrafluorobenzaldehyde [9]. Yield: 66\%; mp $45-47^{\circ} \mathrm{C}$ dec. (Lit. $44-45^{\circ} \mathrm{C}$.) IR (nujol): $v\left(\mathrm{~cm}^{-1}\right) 2120$ ( $\mathrm{N}_{3}$ azide), 1697 ( $\mathrm{C}=\mathrm{O}$ aldehyde). ${ }^{1} \mathrm{H}$ NMR $\left(200 \mathrm{MHz}, \mathrm{CDCl}_{3}\right) \delta 10.24(\mathrm{~s}, 1 \mathrm{H}$, $\mathrm{CHO}) .{ }^{19} \mathrm{~F} \mathrm{NMR}\left(\mathrm{CDCl}_{3}\right): \delta 150.8-151.1(\mathrm{~m}, 2 \mathrm{~F}), 144.7-145.0(\mathrm{~m}, 2 \mathrm{~F})$. MS: $m / z 219\left(\mathrm{M}^{+}\right)$.

2.1.9.2. 2-Azido-3,4,5,6-tetrafluorobenzaldehyde [10]. Yield: 10\%; mp 40-42 ${ }^{\circ} \mathrm{C} \mathrm{dec}$. IR (nujol): $v\left(\mathrm{~cm}^{-1}\right) 2121\left(\mathrm{~N}_{3}\right.$ azide), $1712(\mathrm{C}=\mathrm{O}$ aldehyde). ${ }^{1} \mathrm{H}$ NMR (200 MHz, $\left.\mathrm{CDCl}_{3}\right) \delta 10.24$ (s, 1H, CHO). ${ }^{19} \mathrm{~F}$ NMR $\left(\mathrm{CDCl}_{3}\right): \delta 149.7(\mathrm{~d}, 1 \mathrm{~F}), 143.8-144.2(\mathrm{~m}, 2 \mathrm{~F}), 139.8$ (d, 1F). MS: $m / z$ $219\left(\mathrm{M}^{+}\right)$.

\subsubsection{Synthesis of [4-(bromomethyl)phenyl](phenyl)methanone}

[5c] (Zhao et al., 1997)

Dibenzoylperoxide $(0.122 \mathrm{mmol})$ was added to a mixture of $\mathbf{1 3}$ $(3.06 \mathrm{mmol})$ and NBS $(4.28 \mathrm{mmol})$ in carbon tetrachloride $(16 \mathrm{~mL})$. The reaction was refluxed for $76 \mathrm{~h}$ and then was cooled down to r.t., filtered and the solid obtained was washed with carbon tetrachloride. The filtrate was concentrated in vacuo to give a yellow solid that was purified by silica gel column chromatography eluting with petroleum ether/ethyl acetate $9.5 / 0.5$ to afford a yellow solid. Yield: 69\%; mp 109-111 ${ }^{\circ} \mathrm{C}$ dec. (Lit. $110-112{ }^{\circ} \mathrm{C}$.) IR (nujol): $v \mathrm{~cm}^{-1} 1645$
( $\mathrm{C}=\mathrm{O}$ ketone). ${ }^{1} \mathrm{H}$ NMR $\left(200 \mathrm{MHz}, \mathrm{CDCl}_{3}\right) \delta 7.82-7.77(\mathrm{~m}, 4 \mathrm{H}, \mathrm{Ar}-\mathrm{H})$, 7.60-7.45 (m, 5H, Ar-H), 4.54 (s, 2H, $\left.\mathrm{CH}_{2}\right)$. MS: m/z $275\left(\mathrm{M}^{+}\right)$.

\subsubsection{Synthetic procedure for}

(4-methylphenyl)(phenyl)methanone [13] (Gobbi et al., 2007)

$\mathrm{AlCl}_{3}(16.2 \mathrm{mmol})$ was added portion-wise to a solution of $p$ toluoylchloride $12(6.47 \mathrm{mmol})$ in dry benzene $(17.2 \mathrm{~mL})$ cooled with an ice bath. The mixture was stirred at the same temperature for $1 \mathrm{~h}$ and at $60^{\circ} \mathrm{C}$ for $2 \mathrm{~h}$. Then, the reaction was cooled down to r.t., poured into $150 \mathrm{~mL}$ of $3 \mathrm{~N} \mathrm{HCl}$ and extracted with ethyl acetate. The combined organic layers were washed with water, dried over sodium sulfate, filtered and the solvent was removed in vacuo to give a yellow oil that solidifies at r. t. Yield: $98 \%$; $\mathrm{mp} 48-50{ }^{\circ} \mathrm{C} \mathrm{dec}$. (Lit. oil.) IR (nujol): $v\left(\mathrm{~cm}^{-1}\right) 1663$ ( $\mathrm{C}=\mathrm{O}$ ketone). ${ }^{1} \mathrm{H}$ NMR $(200 \mathrm{MHz}$, $\left.\mathrm{CDCl}_{3}\right) \delta$ 7.81-7.76 (m, 4H, Ar-H), 7.58-7.43 (m, 5H, Ar-H), $2.44(\mathrm{~s}$ $\left.3 \mathrm{H}, \mathrm{CH}_{3}\right)$. MS: $m / z 196\left(\mathrm{M}^{+}\right)$.

\subsubsection{Synthesis of 1-[5-(4-fluorobenzyl)-2-furyl]ethanone [14] (Short approach)}

To a solution of acetylfuran $3(9.1 \mathrm{mmol})$ in dry DCM $(4 \mathrm{~mL})$ was added 1-(bromomethyl)-4-fluorobenzene $\mathbf{2 2}$ (13.7 mmol) followed by $\mathrm{FeCl}_{3} 97 \%$ (2.73 mmol). After further addition of dry DCM $(2 \mathrm{~mL})$ the mixture was stirred at reflux for $48 \mathrm{~h}$. Then, the reaction was cooled down to r.t. and quenched with water, extracted with DCM and the combined organic layers were washed with water, dried over sodium sulfate and filtered. The solvent was removed in vacuo to give a brown oil that was purified by silica gel column chromatography eluting with petroleum ether/ethyl acetate 8.5/1.5 to afford a pale yellow oil. Yield: $7 \%$. Oil at r.t. IR (nujol): $v\left(\mathrm{~cm}^{-1}\right) 1672(\mathrm{C}=0$ ketone). ${ }^{1} \mathrm{H}$ NMR $\left(200 \mathrm{MHz}, \mathrm{CDCl}_{3}\right) \delta 7.24-7.18(\mathrm{~m}, 2 \mathrm{H}, \mathrm{Ar}-\mathrm{H}), 7.09$ (d, 1H, Ar-H furan), 7.04-6.98 (t, 2H, Ar-H), 6.09 (d, 1H, Ar-H furan), 4.01(s, $\left.2 \mathrm{H}, \mathrm{CH}_{2}\right), 2.43\left(\mathrm{~s}, 3 \mathrm{H}, \mathrm{CH}_{3}\right)$. MS: $m / z 218\left(\mathrm{M}^{+}\right)$.

\subsubsection{Synthesis of 1-[5-(4-fluorobenzyl)-2-furyl]ethanone [14] (Longer approach)}

A $3 \mathrm{M}$ solution of methylmagnesium bromide in diethyl ether (1.1 eq) was slowly added to a solution of $21(5.27 \mathrm{mmol})$ in dry $\mathrm{THF}(58 \mathrm{~mL})$ at $0{ }^{\circ} \mathrm{C}$ and under a nitrogen atmosphere. The reaction mixture was stirred at the same temperature for $1 \mathrm{~h}$ and then was quenched with a $10 \%$ aqueous solution of $\mathrm{NH}_{4} \mathrm{Cl}$ and extracted with diethyl ether. The combined organic layers were dried over sodium sulfate, filtered and the solvent was removed in vacuo to give an orange oil that was purified by silica gel column chromatography eluting with petroleum ether/ethyl acetate $8 / 2$ to afford a yellow oil. Yield: 54\%. Oil at r.t. IR (nujol): $v\left(\mathrm{~cm}^{-1}\right) 1672\left(\mathrm{C}=\mathrm{O}\right.$ ketone). ${ }^{1} \mathrm{H}$ NMR (200 MHz, CDCl $\left.)_{3}\right) \delta$ 7.24-7.18 (m, 2H, Ar-H), 7.09 (d, 1H, Ar-H furan), 7.04-6.98 (t, 2H, Ar-H), 6.09 (d, 1H, Ar-H furan), 4.01(s, $2 \mathrm{H}$, $\left.\mathrm{CH}_{2}\right), 2.43\left(\mathrm{~s}, 3 \mathrm{H}, \mathrm{CH}_{3}\right)$. MS: $m / z 218\left(\mathrm{M}^{+}\right)$.

\subsubsection{Synthesis of S-pyridin-2-yl}

5-(4-fluorobenzyl)furan-2-carbotioate [21]

A mixture of triphenylphosphine (1.2 eq) and $20(6.81 \mathrm{mmol})$ in dry acetonitrile $(50 \mathrm{~mL})$ was stirred at $10^{\circ} \mathrm{C}$ for $1.5 \mathrm{~h}$. Then the solvent was removed in vacuo to give a brown orange oil that was purified by silica gel column chromatography eluting with petroleum ether/ethyl acetate $8 / 2$ to give a solid that was triturated from petroleum ether to afford an orange solid. Yield: $63 \%$; mp 77-78 ${ }^{\circ} \mathrm{C}$ dec. IR (nujol): $v\left(\mathrm{~cm}^{-1}\right) 1649$ ( $\mathrm{C}=\mathrm{O}$ ester). ${ }^{1} \mathrm{H}$ NMR $\left(200 \mathrm{MHz}, \mathrm{CDCl}_{3}\right) \delta 8.67-8.64(\mathrm{~m}, 1 \mathrm{H}, \mathrm{Ar}-\mathrm{H}), 7.78-7.72(\mathrm{~m}, 2 \mathrm{H}$, $\mathrm{Ar}-\mathrm{H}), 7.35-7.29(\mathrm{~m}, 1 \mathrm{H}, \mathrm{Ar}-\mathrm{H}), 7.27-7.22(\mathrm{~m}, 2 \mathrm{H}, \mathrm{Ar}-\mathrm{H}), 7.20(\mathrm{~d}$, $1 \mathrm{H}, \mathrm{Ar}-\mathrm{H}$ furan ), 7.07-7.02 (m, 2H, Ar-H), 6.15 (d, 1H, Ar-H furan), $4.04\left(\mathrm{~s}, 2 \mathrm{H}, \mathrm{CH}_{2}\right)$. MS: $m / z 313\left(\mathrm{M}^{+}\right)$.

\subsubsection{Synthesis of 5-(4-fluorobenzyl)-2-furoic acid [20]}

A solution of $\mathrm{NaI}$ (5.0 eq) and chlorotrimethylsilane (5.0 eq) in dry acetonitrile $(13 \mathrm{~mL})$ was stirred at $0{ }^{\circ} \mathrm{C}$ under a nitrogen 
atmosphere for $15 \mathrm{~min}$. Then, a solution of $\mathbf{1 9}(9.31 \mathrm{mmol})$ in dry acetonitrile $(33 \mathrm{~mL})$ was slowly added and the reaction mixture was stirred at r.t. for $4 \mathrm{~h}$. The reaction was quenched with water and extracted with ethyl acetate. The combined organic layers were washed with a solution of $\mathrm{Na}_{2} \mathrm{~S}_{2} \mathrm{O}_{4} \cdot 5 \mathrm{H}_{2} \mathrm{O}$ (2.1 eq) in water $(22 \mathrm{~mL})$ and brine, dried over sodium sulfate, filtered and the solvent was removed in vacuo to give a solid that was triturated from petroleum ether to afford an orange solid (yield $77 \%$ ). mp $108-110^{\circ} \mathrm{C}$ dec. IR (nujol): $v\left(\mathrm{~cm}^{-1}\right) 1672$ ( $\mathrm{C}=\mathrm{O}$ acid). ${ }^{1} \mathrm{H}$ NMR $\left(200 \mathrm{MHz}\right.$, DMSO- $\left.d_{6}\right) \delta$ 12.90 (brs, $1 \mathrm{H}, \mathrm{OH}$, exchange with $\left.\mathrm{D}_{2} \mathrm{O}\right), 7.33-7.26(\mathrm{~m}, 2 \mathrm{H}, \mathrm{Ar}-\mathrm{H})$, 7.15-7.11 ( $\mathrm{m}, 3 \mathrm{H}, \mathrm{Ar}-\mathrm{H}$, benzene and furan), 6.31 (d, $1 \mathrm{H}, \mathrm{Ar}-\mathrm{H}$, furan), $4.05\left(\mathrm{~s}, 2 \mathrm{H}, \mathrm{CH}_{2}\right)$. MS: $m / z 220\left(\mathrm{M}^{+}\right)$.

\subsubsection{Synthesis of 5-[(4-fluorophenyl)(hydroxy)methyl]-2-furoic acid [19]}

A solution of LDA [prepared from n-BuLi $2.5 \mathrm{M}$ in $n$-hexane $(21.4 \mathrm{~mL}, 53.6 \mathrm{mmol})$ and diisopropylamine $(53.6 \mathrm{mmol})$ in dry THF $(51 \mathrm{~mL})$ ] was stirred at $-78^{\circ} \mathrm{C}$ under a nitrogen atmosphere for $15 \mathrm{~min}$. Then, a solution of furoic acid $\mathbf{1 8}(26.8 \mathrm{mmol})$ in dry THF $(15 \mathrm{~mL})$ was added and the reaction mixture was stirred at $-78^{\circ} \mathrm{C}$ for $30 \mathrm{~min}$. $p$-Fluorobenzaldehyde $17(26.8 \mathrm{mmol})$ was slowly added. The reaction mixture was stirred at the same temperature for $4 \mathrm{~h}$, quenched with water, acidified with $3 \mathrm{~N} \mathrm{HCl}$, and extracted with diethyl ether. The combined organic layers were evaporated in vacuo to give a yellow oil that was dissolved in ethyl acetate and extracted with a $5 \%$ aqueous solution of $\mathrm{NaHCO}_{3}$. The combined basic aqueous layers were acidified with $3 \mathrm{~N} \mathrm{HCl}$ to afford a yellow oil that solidified and was triturated with petroleum ether/diethyl ether to give a pale yellow solid. Yield: 53\%; mp 174-176 ${ }^{\circ} \mathrm{C}$ dec. IR (nujol): $v\left(\mathrm{~cm}^{-1}\right) 1694$ ( $\mathrm{C}=\mathrm{O}$ acid). ${ }^{1} \mathrm{H}$ NMR $\left(200 \mathrm{MHz}, \mathrm{CDCl}_{3}\right) \delta 7.37-7.33(\mathrm{~m}, 2 \mathrm{H}, \mathrm{Ar}-\mathrm{H}), 7.07(\mathrm{~d}, 1 \mathrm{H}, \mathrm{Ar}-\mathrm{H}$, furan), 6.99 (t, 2H, Ar-H), 6.06 (d, 1H, Ar-H, furan), $5.77(\mathrm{~s}, 1 \mathrm{H}, \mathrm{CH})$. MS: $m / z 236\left(\mathrm{M}^{+}\right)$.

\subsubsection{Synthesis of ethyl 1-trityl-1H-1,2,4-triazol-5-carboxylate}

[15] (Norcross et al., 1997)

Triethylamine $(2.21 \mathrm{~mL})$ and chlorotriphenylmethane (8.43 $\mathrm{mmol}$ ) were added to a solution of compound $\mathbf{2 6}$ (7.94 $\mathrm{mmol})$ in dry DMF (27 mL) at r.t. The mixture was stirred for $15 \mathrm{~min}$ at r.t. and quenched with water. The precipitate formed was filtered and washed with water and diethyl ether to afford a white solid. Yield: 95\%; mp 157-158 ${ }^{\circ} \mathrm{C}$ dec. IR (nujol): $v\left(\mathrm{~cm}^{-1}\right) 1739$ ( $\mathrm{C}=\mathrm{O}$ ester). ${ }^{1} \mathrm{H}$ NMR $\left(200 \mathrm{MHz}, \mathrm{CDCl}_{3}\right) \delta 8.01(\mathrm{~s}, 1 \mathrm{H}, \mathrm{Ar}-\mathrm{H}), 7.36-7.31(\mathrm{~m}, 9 \mathrm{H}$, $\mathrm{Ar}-\mathrm{H}), 7.13-7.11$ (m, 6H, $\mathrm{Ar}-\mathrm{H}), 4.45$ (q, $\left.2 \mathrm{H}, \mathrm{CH}_{2}\right), 1.41$ (t, 3H, $\mathrm{CH}_{3}$ ). MS: $m / z 383\left(\mathrm{M}^{+}\right)$.

\subsubsection{Synthesis of ethyl 1H-1,2,4-triazol-5-carboxylate [26]} (Vanek et al., 1984)

A suspension of $\mathbf{2 5}(6.3 \mathrm{mmol})$ in diglyme ( $4 \mathrm{~mL}$ ) was stirred at reflux for $1.5 \mathrm{~h}$. Then, the reaction was cooled to r.t. and the precipitate formed was filtered and washed with $n$-hexane to give a white solid. Yield: $81 \%$; mp $168-169{ }^{\circ} \mathrm{C}$ dec. (Lit. $176-178{ }^{\circ} \mathrm{C}$.) IR (nujol): $v$ $\left(\mathrm{cm}^{-1}\right) 1713$ (C=O ester). ${ }^{1} \mathrm{H}$ NMR $\left(200 \mathrm{MHz}, \mathrm{CDCl}_{3}\right) \delta 8.53(\mathrm{~s}, 1 \mathrm{H}$, $\mathrm{Ar}-\mathrm{H}), 4.53$ (q, 2H, $\left.\mathrm{CH}_{2}\right), 1.47\left(\mathrm{t}, 3 \mathrm{H}, \mathrm{CH}_{3}\right) . \mathrm{MS}: \mathrm{m} / z 141\left(\mathrm{M}^{+}\right)$.

\subsubsection{Synthesis of amino(formylhydrazo) ethyl acetate [25]} (Vanek et al., 1984)

A mixture of ethyl thioxammate $24(5.6 \mathrm{mmol})$ and formylhydrazine $23(5.9 \mathrm{mmol})$ was heated at $65^{\circ} \mathrm{C}$ for $1 \mathrm{~h}$. The reaction then was cooled to r.t. and the solid formed was filtered and washed with ethanol to afford a pale yellow solid. Yield: $60 \%$; $\mathrm{mp} 148-149{ }^{\circ} \mathrm{C} \mathrm{dec}$. (Lit. $159-160{ }^{\circ} \mathrm{C}$.) IR (nujol): $v\left(\mathrm{~cm}^{-1}\right) 3311\left(\mathrm{NH}_{2}\right.$ primary amine), 3199 ( $\mathrm{NH}$ amide), 1735 ( $\mathrm{C}=\mathrm{O}$ ester), 1645 ( $\mathrm{C}=\mathrm{O}$ amide). ${ }^{1} \mathrm{H}$ NMR $\left(200 \mathrm{MHz}, \mathrm{CDCl}_{3}+\mathrm{DMSO}_{-} \mathrm{d}_{6}\right) \delta 10.60-10.31(\mathrm{~m}, 1 \mathrm{H}, \mathrm{NH}$, exchange with $\left.\mathrm{D}_{2} \mathrm{O}\right), 8.60(\mathrm{~d}, 1 \mathrm{H}, \mathrm{CHO}), 6.21\left(\mathrm{~s}, 2 \mathrm{H}, \mathrm{NH}_{2}\right.$, exchange with $\left.\mathrm{D}_{2} \mathrm{O}\right)$, $4.31\left(\mathrm{q}, 2 \mathrm{H}, \mathrm{CH}_{2}\right), 1.35\left(\mathrm{t}, 3 \mathrm{H}, \mathrm{CH}_{3}\right)$. MS: $\mathrm{m} / \mathrm{z} 159\left(\mathrm{M}^{+}\right)$.

\subsubsection{Synthesis of 1-[5-(4-fluorobenzyl)-2-furyl]-3-hydroxy-3-}

(1H-1,2,4-triazol-5-yl)prop-2-en-1-one [II]

(S-1360)

$\mathrm{HCl} 3 \mathrm{~N}(7.8 \mathrm{~mL})$ was added to a solution of compound $\mathbf{1 6}$ $(2.34 \mathrm{mmol})$ in 1,4-dioxane $(30 \mathrm{~mL})$ and the mixture was stirred at $80^{\circ} \mathrm{C}$ for $30 \mathrm{~min}$. Then the reaction was cooled to r.t. and the solvent was evaporated in vacuo to give a residue that was dissolved in diethyl ether and was extracted with $1 \mathrm{~N} \mathrm{NaOH}$. The combined aqueous layers were acidified with $3 \mathrm{~N} \mathrm{HCl}$ and the precipitate formed was filtered and washed with water and ethyl acetate. The solid residue was crystallized from ethyl acetate to afford a yellow solid. Yield: $38 \%$; mp $178-179{ }^{\circ} \mathrm{C} \mathrm{dec}$. IR (nujol): $v\left(\mathrm{~cm}^{-1}\right) 3580(\mathrm{NH}$ triazole). ${ }^{1} \mathrm{H}$ NMR (200 MHz DMSO-d $\left.d_{6}\right) \delta 8.77$ (brs, $1 \mathrm{H}, \mathrm{NH}$, exchange with $\left.\mathrm{D}_{2} \mathrm{O}\right), 7.51(\mathrm{~d}, 1 \mathrm{H}, \mathrm{Ar}-\mathrm{H}), 7.37-7.31(\mathrm{~m}, 2 \mathrm{H}, \mathrm{Ar}-\mathrm{H}), 7.17(\mathrm{t}, 2 \mathrm{H}$, $\mathrm{Ar}-\mathrm{H}), 6.93$ (s, 2H, CH), 6.47 (d, 1H, Ar-H), 4.15 (s, 2H, $\mathrm{CH}_{2}$ ). MS: $m / z$ $313\left(\mathrm{M}^{+}\right)$. Anal. Calc. for $\left(\mathrm{C}_{16} \mathrm{H}_{12} \mathrm{FN}_{3} \mathrm{O}_{3}\right)$ : C, 61.34; $\mathrm{H}, 3.86 ; \mathrm{N}, 13.41$. Found: C,60.89; $\mathrm{H}, 3.98 ; \mathrm{N}, 13.65$.

\subsubsection{Synthesis of 1-[5-(4-fluorobenzyl)-2-furyl]-3-hydroxy-3- (1-trityl-1,2,4-triazol-5-yl)prop-2-en-1-one}

\section{[16]}

A $1 \mathrm{M}$ solution of LHMDS in THF $(3.87 \mathrm{mmol})$ was added at $-70^{\circ} \mathrm{C}$ to a solution of $\mathbf{1 4}(2.98 \mathrm{mmol})$ in THF $(9 \mathrm{~mL})$ under nitrogen atmosphere. The reaction mixture was slowly warmed to $-10^{\circ} \mathrm{C}$ and cooled to $-70^{\circ} \mathrm{C} . \mathbf{1 5}(3.87 \mathrm{mmol})$ in THF $(15 \mathrm{~mL})$ was added and the reaction mixture was slowly warmed to r.t. and stirred at the same temperature for $1.5 \mathrm{~h}$. The reaction was quenched with a $10 \%$ aqueous solution of $\mathrm{NH}_{4} \mathrm{Cl}$ and was acidified with $3 \mathrm{~N} \mathrm{HCl}$. The solution was extracted with ethyl acetate and the combined organic layers were washed with brine and dried over sodium sulfate, filtered and the solvent removed in vacuo to give an orange solid that was triturated from diethyl ether to afford a pale orange solid. Yield: 87\%; mp 207-209 ${ }^{\circ} \mathrm{C}$ dec. IR (nujol): $v\left(\mathrm{~cm}^{-1}\right) 1624$ ( $\mathrm{C}=0$ ketone). ${ }^{1} \mathrm{H} \mathrm{NMR}\left(200 \mathrm{MHz} \mathrm{CDCl}_{3}\right) \delta$ 7.53-7.33 (m, 12H, Ar-H), 7.20-7.06 (m, $9 \mathrm{H}, \mathrm{Ar}-\mathrm{H}), 6.91(\mathrm{~s}, 1 \mathrm{H}, \mathrm{CH}), 6.47(\mathrm{~d}, 1 \mathrm{H}, \mathrm{Ar}-\mathrm{H}), 4.14\left(\mathrm{~s}, 2 \mathrm{H}, \mathrm{CH}_{2}\right) . \mathrm{MS}$ : $m / z 555\left(\mathrm{M}^{+}\right)$.

\subsection{Biology}

\subsubsection{Materials, chemicals, and enzymes}

All compounds were dissolved in DMSO and the stock solutions were stored at $-20^{\circ} \mathrm{C}$. The $\gamma\left[{ }^{32} \mathrm{P}\right]$-ATP was purchased from either Amersham Biosciences or ICN. The expression systems for the wildtype IN was a generous gift of Dr Robert Craigie, Laboratory of Molecular Biology, NIDDK, NIH, Bethesda, MD.

\subsubsection{Preparation of oligonucleotide substrates}

The oligonucleotides 21-top, 5'-GTGTGGAAAATCTCTAGCAGT-3' and 21-bot, 5'-ACTGCTAGAGATTTTCCACAC-3' were purchased from Norris Cancer Center Microsequencing Core Facility (University of Southern California) and purified by UV shadowing on polyacrylamide gel. To analyze the extent of strand transfer using $5^{\prime}$-end labeled substrates, 21-top was $5^{\prime}$-end labeled using $\mathrm{T}_{4}$ polynucleotide kinase (Epicentre, Madison, WI) and $\gamma\left[{ }^{32} \mathrm{P}\right]-A T P$ (Amersham Biosciences or ICN). The kinase was heat-inactivated and 21-bot was added in $1.5 \mathrm{M}$ excess. The mixture was heated at $95^{\circ} \mathrm{C}$, allowed to cool slowly to room temperature, and run through a spin 25 mini-column (USA Scientific) to separate annealed double-stranded oligonucleotide from unincorporated material.

\subsubsection{Integrase assays}

To determine the extent of strand transfer, wild-type IN was preincubated at a final concentration of $200 \mathrm{nM}$ with the inhibitor 
in reaction buffer ( $50 \mathrm{mM} \mathrm{NaCl}, 1 \mathrm{mM}$ HEPES, pH 7.5, $50 \mu \mathrm{M}$ EDTA, $50 \mu \mathrm{M}$ dithiothreitol, $10 \%$ glycerol (w/v), $7.5 \mathrm{mM} \mathrm{MnCl} 2,0.1 \mathrm{mg} / \mathrm{mL}$ bovine serum albumin, $10 \mathrm{mM}$ 2-mercaptoethanol, 10\% DMSO and $25 \mathrm{mM}$ MOPS, $\mathrm{pH} \mathrm{7.2)}$ at $30^{\circ} \mathrm{C}$ for $30 \mathrm{~min}$. Then, $20 \mathrm{nM}$ of the $5^{\prime}-$ end ${ }^{32} \mathrm{P}$-labeled linear oligonucleotide substrate was added, and incubation was continued for an additional $1 \mathrm{~h}$. Reactions were quenched by the addition of an equal volume $(16 \mu \mathrm{L})$ of loading dye (98\% deionized formamide, $10 \mathrm{mM}$ EDTA, $0.025 \%$ xylene cyanol and $0.025 \%$ bromophenol blue). An aliquot $(5 \mu \mathrm{L})$ was electrophoresed on a denaturing $20 \%$ polyacrylamide gel ( $0.09 \mathrm{M}$ tris-borate $\mathrm{pH} 8.3$, 2 mM EDTA, 20\% acrylamide, $8 \mathrm{M}$ urea).

Gels were dried, exposed in a PhosphorImager cassette, and analyzed using a Typhoon 8610 Variable Mode Imager (Amersham Biosciences) and quantitated using ImageQuant 5.2. Percent inhibition (\% I) was calculated using the following equation:

$\% I=100 \times\left[1-\frac{D-C}{N-C}\right]$

where $C, N$, and $D$ are the fractions of 21-mer substrate converted to strand transfer products for DNA alone, DNA plus IN, and IN plus drug, respectively. The $\mathrm{IC}_{50}$ values were determined by plotting the logarithm of drug concentration versus percent inhibition to obtain the concentration that produced $50 \%$ inhibition.

\subsection{Molecular modeling}

Model compounds L-731,988 (I) and Ia-c, and S-1360 (II) and IIac were constructed with standard bond lengths and angles from the fragment database with MacroModel 6.0 using a Silicon Graphics $\mathrm{O} 2$ workstation running on IRIX 6.3. Sybyl 6.2 as graphic platform. The atomic charges were assigned using the Gasteiger-Marsili method (Gasteiger and Marsili, 1980). Minimization of structures was performed with the MacroModel/BachMin 6.0 program using the AMBER force field. An extensive conformational search was carried out using the Monte Carlo/energy minimization (Chang et al., 1989) for all the compounds considered in the study (Ei-Emin $<5 \mathrm{kcal} / \mathrm{mol}$, energy difference between the generated conformation and the current minimum). Representative minimum energy conformations of each compounds were optimized using the $a b$ initio quantum chemistry program Gaussian 98 with method B3LYP/6-311G basis set. Moreover, compounds I and II were submitted to quantum mechanics calculation by using B3LYP/6-311G method. Gaussian and docking calculations were performed on HP Exemplar Parallel Server V2200 running HP UX 11.0.

Subunit A of the IN core domain in complex with 1-(5chloroindol-3-yl)-3-hydroxy-3-(2H-tetrazol-5-yl-propenone) (5CITEP; PDB 1QS4) (Goldgur et al., 1999) was used for all docking studies. The missing residues at positions 141-144 in this subunit were incorporated from monomer B of the IN structure PDB 1BIS after superimposition of the backbone residues 135-140 and 145-150, as previously reported (Sechi et al., 2004a; Sotriffer et al., 2000a,b). Docking was performed with AutoDock version 3.05 (Morris et al., 1996) using the new empirical free energy function and the Lamarckian protocol (Morris et al., 1998). Mass-centered grid maps were generated with 80 grid points for every direction,

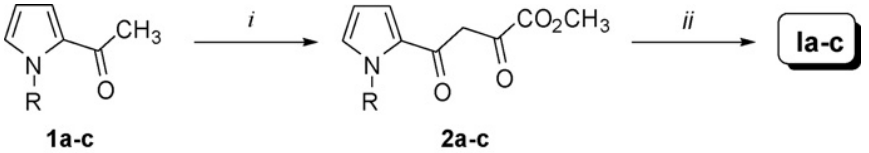

Scheme 1. Preparation of compound I (L-731,988) and photoprobes Ia-c.

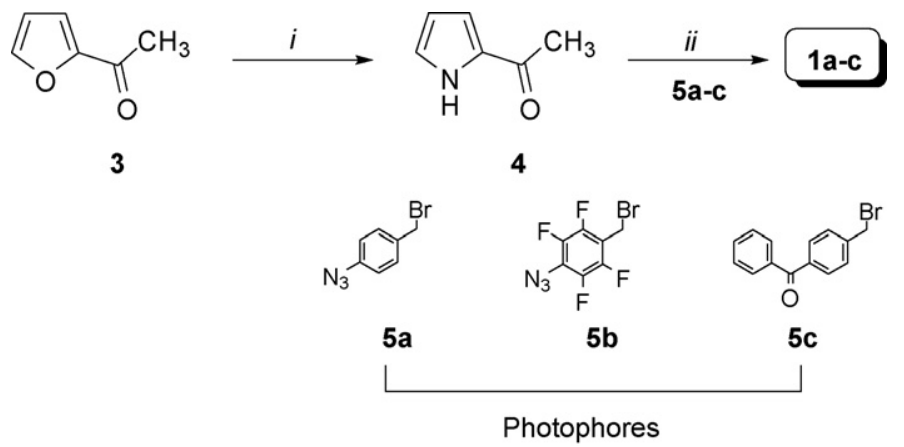

Scheme 2. Preparation of the ester intermediates $\mathbf{1}$ and 1a-c.

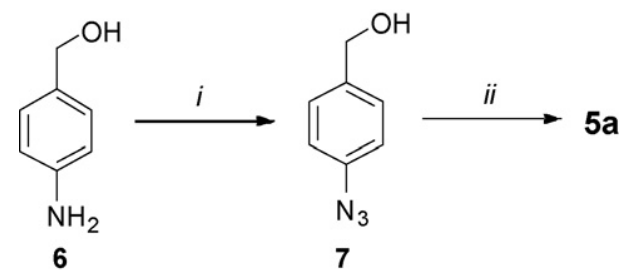

Scheme 3. Preparation of photophore 5a.

and with 0.375 Angstroms spacing by the AutoGrid program for the whole protein target. Random starting position on the entire protein surface, random orientations, and torsions were used for the ligands. The distance-dependent dieletric permittivity of Mehler and Solmajer was used for the calculation of the electrostatic gridmaps. 100 independent docking runs were carried out for each ligand. The cluster analysis was computed with a cluster tolerance at less than $1.5 \AA$ in positional root-mean-square deviation.

\section{Results and discussion}

\subsection{Chemistry}

We used a common synthetic strategy to prepare the target compounds Ia-c and IIa-c. Synthetic approaches for the preparation of reference compounds I and II and the photolabeled derivatives Ia-c are depicted in Schemes 1-8.

DKAs Ia-c were obtained following the same procedure already used for the preparation of the reference compound I. In particular, Ia-c were obtained by alkaline hydrolysis of their respective $\beta$-diketo esters 2a-c. The latter were synthesized by Claisen condensation of the appropriate acetyl-derivatives 1a-c with

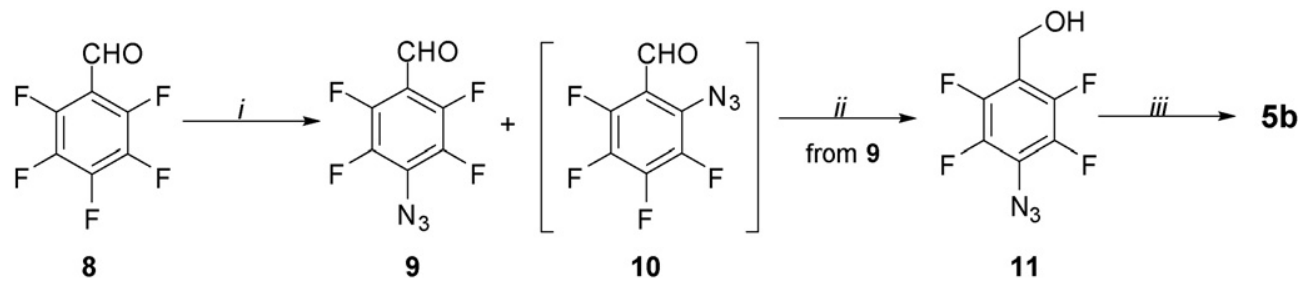

Scheme 4. Preparation of photophore $\mathbf{5 b}$. 


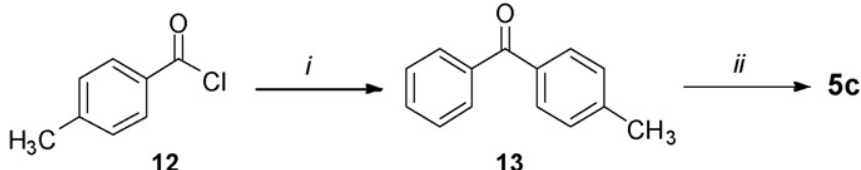

Scheme 5. Preparation of photophore 5c.

dimethyloxalate in the presence of sodium hydride in anhydrous DMF (Scheme 1). The intermediates 1a-c were easily obtained by adapting a method previously reported by our group (Sechi et al., 2004b, 2006). Pyrrolization of 2-acetylfuran 3 with $30 \%$ acqueous $\mathrm{NH}_{3}$ in sealed tube at $160^{\circ} \mathrm{C}$ afforded the intermediate 4 in good yield. Alkylation of the 2-acetylpyrrole 4 with the appropriate benzylbromide in powdered $\mathrm{KOH} / \mathrm{DMSO}$ gave the corresponding alkylpyrrole 1a-c (Scheme 2). The photophore 4azide-benzylbromide $\mathbf{5 a}$ was obtained by a Sandmeyer reaction of the aminobenzylalcohol 6 to give the azidobenzylalcohol 7 (Griffin, 1996), which was converted to the desired benzylbromide 5a using $\mathrm{PBr}_{3}$ (Scheme 3).

The tetrafluoroarylazide $\mathbf{5 b}$ was prepared by substitution of the fluorine in 4-position of the pentafluorobenzaldehyde 8 with $\mathrm{NaN}_{3}$ to give $\mathbf{9}$ (Keana and Xiong Cai, 1990) (with a small amount of the orto-isomer 10), followed by a reduction of the aldehyde group with dimethylamonoborane to afford the alcohol 11. The latter was then brominated in the presence of $\mathrm{PBr}_{3}$ in $\mathrm{CH}_{2} \mathrm{Cl}_{2}$ to give the desired benzylbromide $\mathbf{5 b}$ (Lei and Atkinson, 2000) (Scheme 4). Then, the photophore benzophenone $\mathbf{5 c}$ was synthesized by a Friedel-Craft acylation of the $p$-tolylchloride $\mathbf{1 2}$ with benzene to give the benzophenone 13 (Smith, 1921), which was brominated with NBS and catalytic dibenzoyl peroxide to afford the benzyl bromide $\mathbf{5 c}$ (Tanaka et al., 1998) (Scheme 5).

Another goal was to prepare the reference compound, S-1360 (II), in order to find a versatile synthetic route that could be used for the preparation of the photoprobes IIa-c. The preparation of II was formally the same as used for Ia-c, which followed a Claysentype reaction between the synthones 14 and 15. Both synthones were then coupled by treating with $1 \mathrm{M}$ LHMDS at $-70^{\circ} \mathrm{C}$ to give the protected compound $\mathbf{1 6}$ in $\mathbf{8 7 \%}$ yield (Scheme 6). Hydrolysis of the trityl group by $3 \mathrm{~N} \mathrm{HCl}$ gave the desired II.

The synthon 14 was prepared by reacting the acid 20 with dipyridyldisulfide in the presence of $\mathrm{Ph}_{3} \mathrm{P}$ to give the thioate 21, which, after treating with $3 \mathrm{M} \mathrm{CH}_{3} \mathrm{MgBr}$ (Araki et al., 1974), afforded 14 in good yield (Scheme 7A). Interestingly, the acid intermediate 20 was also obtained by a tandem-reaction between the p-fluorobenzaldehyde 17 and the 2-furoic acid 18 using 1.8 M LDA in THF (Knight, 1979) to give the alcohol 19, followed by reduction in the presence of TMSCl and NaI (Stoner et al., 1995) (Scheme 7A). We also obtained the desired synthon 14 by a direct alkylation between the benzylbromide $\mathbf{2 2}$ and the 2-acetylfuran 3, albeit in low yield (Scheme 7B).

The synthon 15 was synthesized by heating both the formylhydrazine $\mathbf{2 3}$ and the thioamide $\mathbf{2 4}$ to give the acylamidrazone $\mathbf{2 5}$ (Vanek et al., 1984). The latter was refluxed in diglyme to give<smiles>CC(C)COC(=O)c1ccc(C(=O)O)cc1</smiles>

17

18

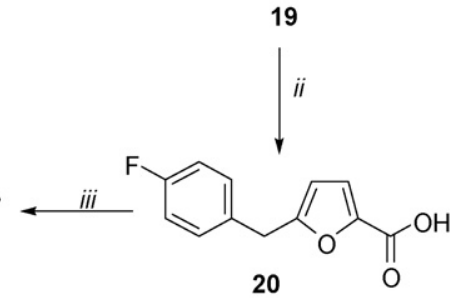

21

iv

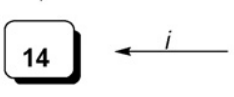<smiles>Fc1ccc(CBr)cc1</smiles>

22
Scheme 7. Preparation of synthon 7.<smiles>CC#CC1CCC[C@H]1CC#CCC(=O)OCC</smiles>

Scheme 8. Preparation of synthon 8.

the acetyltriazole 26, which was protected with chlorotriphenylmethane (Norcross et al., 1997) to give 15 in high yield (Scheme 8).

\subsection{Biology}

The photoprobes Ia-c were tested for their ability to inhibit IN catalytic activities in in vitro assays employing purified enzyme. All tested compounds showed anti-IN activity in the low micromolar concentration range. All the compounds of the L-731,988 series inhibited strand transfer reactions with $\mathrm{IC}_{50}$ values of $<3.7 \mu \mathrm{M}$, while the inhibition values against the 3 '-processing catalytic step were in a range from 12 to $28 \mu \mathrm{M}$. Ideally, the photoprobe should be bioactive in the same range as its parent compound, but compounds with as much as 1000 times lower activity can still be useful. In our case it was observed that, in cross-linking assays designed to measure disruption of substrate DNA binding, the photoprobes behaved similarly to a reference DKA inhibitor $\left(\mathrm{IC}_{50 \mathrm{~s}}=<3.7 \mu \mathrm{M}\right.$ and $0.54 \pm 0.08$ against strand transfer, for $\mathbf{I a - c}$ and $\mathbf{I}$, respectively). Therefore, photoprobes Ia-c were selected for further photoaffinity<smiles>CC(=O)c1ccc(Cc2ccc(F)cc2)o1</smiles>

14<smiles>CCOC(=O)c1ncnn1C(c1ccccc1)(c1ccccc1)c1ccccc1</smiles>

15

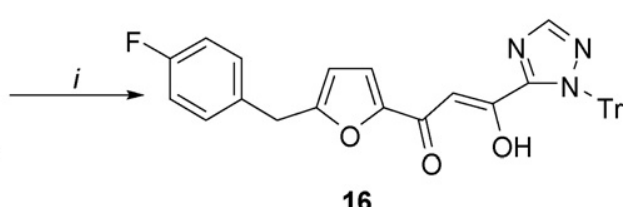

16

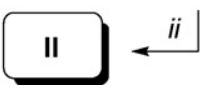

Scheme 6. Preparation of compound II (S-1360). 
labelling studies employing full-length and catalytic core (residues 50-212) units of IN in the presence and absence of substrate DNA, using UV-cross-linking followed by enzyme digestion, separation, and mass spectrometry as recently described (Al-Mawsawi et al., 2006). Studies are in progress for finalizing a general scheme for DKA binding sites.

\subsection{Molecular modeling}

We performed detailed docking studies to predict interaction of I and II and their corresponding photoprobes into the active site of IN. In the absence of key, relevant crystal structures, molecular modeling has been used extensively to assist the understanding of the binding of inhibitors to the IN active site and to aid in the design of novel inhibitors. (Barreca et al., 2003; Chen et al., 2002; Sotriffer et al., 2000a,b; Zeinalipour-Loizidou et al., 2007.) Previously, an Xray structure of one DKA analogue (5CITEP) has been crystallized with the enzyme (Goldgur et al., 1999). To investigate the putative binding modes of the title compounds Ia-c, compared with those of the reference compound I, we used the IN-5CITEP complex (PDB 1QS4) as described (Sechi et al., 2004a; Sotriffer et al., 2000a,b). Considering that the carboxylic group of DKAs has a $\mathrm{p} K_{\mathrm{a}}$ of $\sim 4$ under physiological conditions (Sechi et al., 2006) we modeled L-731,988 and related photoprobes as carboxylates for docking studies. Moreover, since the triazole has a $\mathrm{p} K_{\mathrm{a}}$ of $\sim 9$ (Woodruf and Polya, 1975), we considered the $S-1360$ and its related photoprobes in the neutral form.

Graphical representations of top-ranking binding modes obtained for these ligands showing the important residues involved in binding are depicted in Figs. 3 and 4. The results of clustered docking runs with the most favorable free binding energy are given in Table 1.

According to docking results, the amino acid residues involved in the binding of title compounds located near the catalytic site were as follows: Asp64, Cys65, His67, Asp116, Ser119, Asn120, Gln148, Asn155, Lys156 and Lys159. Several of these were considered to be very important for the activity of IN, and some have been previously shown to play a role in substrate binding (Neamati et al., 2000; Semenova et al., 2008; Sotriffer et al., 2000b). In general, a similar
Table 1

Docking results of 100 independent runs for compounds I, Ia-c, II, IIa-c.

\begin{tabular}{lllll}
\hline Ligand & $N_{\text {tot }^{\mathrm{a}}}{ }^{\mathrm{a}}$ & $f_{\text {occ }}{ }^{\mathrm{b}}$ & $\Delta G_{\text {bind }}{ }^{\mathrm{c}}$ & H-bonds \\
\hline I & 5 & $19 / 11$ & -8.87 & His 67, Gln 148, Asn 155 \\
Ia & 6 & $26 / 13$ & -9.64 & Asp 116, Gln 148, Asn 155 \\
Ib & 6 & $34 / 15$ & -9.82 & Cys 65, His 67, Gln 148 \\
Ic & 7 & $51 / 24$ & -9.20 & Cys 65, Gln 148 \\
II & 5 & $21 / 9$ & -7.75 & Ser 119, Asn 120, Lys 159 \\
IIa & 6 & $34 / 14$ & -8.11 & Ser 119, Asn 120, Lys 156, Lys 159 \\
IIb & 6 & $35 / 14$ & -8.68 & Ser 119, Asn 120, Asn 155, Lys 156, Lys 159 \\
IIc & 7 & $31 / 15$ & -7.23 & Asp 64, Asn 155, Lys 156 \\
\hline
\end{tabular}

a Total number of clusters.

b Number of distinct conformational clusters found out of 100 runs/number of multi-member conformational clusters.

${ }^{c}$ Estimated free binding energy ( $\left.\mathrm{kcal} / \mathrm{mol}\right)$.

mode of binding with the same orientation on the active site was observed for the ligands of each series. In fact, I and Ia-c as well as II and IIa-c show an overlapping orientation in the enzyme site. In particular, we found that I and Ia-c bind within the following amino acid pattern: Cys65, His67, Asp116, Gln148, and Asn155. Moreover, they chelate $\mathrm{Mg}^{2+}$, involving both the 2-enol and carboxylate functionalities (Fig. 3). As far as the disposition of II and photoprobes IIa-c are concerned, they form a planar conformation and achieve favorable interactions with various amino acid residues, such as Asp64, Ser119, Asn120, Asn155, Lys156 and Lys159. In this bound orientation, two oxygen atoms, the oxygen atom in the furan ring and keto group, form coordinate bonds with $\mathrm{Mg}^{2+}$ ion, as already observed (Dayam and Neamati, 2004) (Fig. 4).

The estimated free binding energy values $\left(\Delta G_{\text {bind }}\right)$ of the docked positions, expressed in $\mathrm{kcal} / \mathrm{mol}$, indicated favorable interactions and tight binding with key amino acid residues at the active site of IN. Photoprobes Ia-c showed similar free binding energy, when compared with the reference compound $\mathbf{I}\left(\Delta G_{\text {bind }}=-9.64,-9.82\right.$, -9.20 and $-8.87 \mathrm{kcal} / \mathrm{mol}$ for $\mathbf{I a}, \mathbf{I b}$, Ic and I, respectively). High free binding energy values have also been obtained for the reference compound II and its related photoprobes (Table 2 ).

Then, we performed calculation of electronic density with the aim of understanding how structural changes can affect substrate
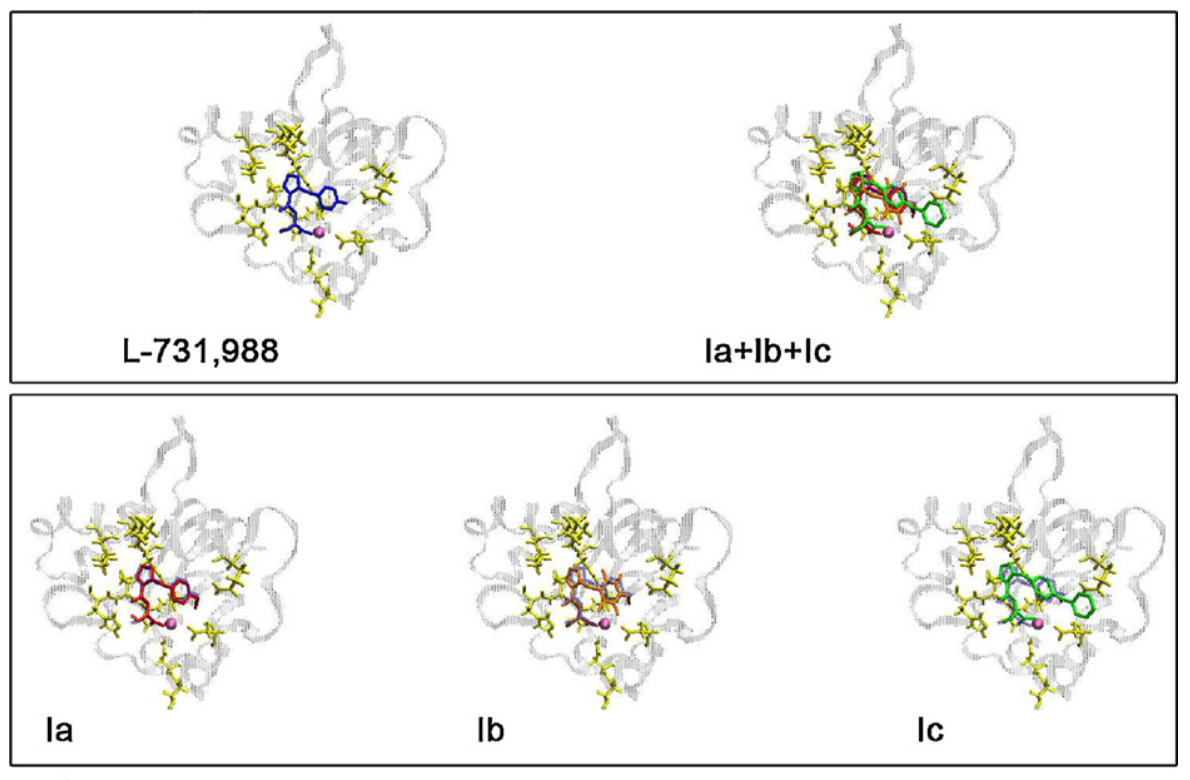

$\mathrm{Mg}^{2+}$ ion is shown in magenta.

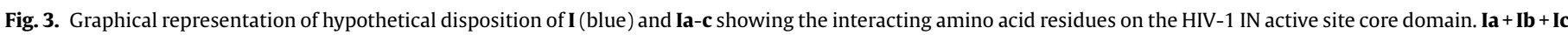

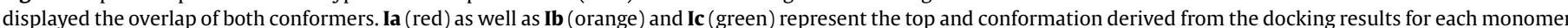
(overlapped with $\mathbf{I}$ ), respectively. (For interpretation of the references to colour in this figure legend, the reader is referred to the web version of the article.) 


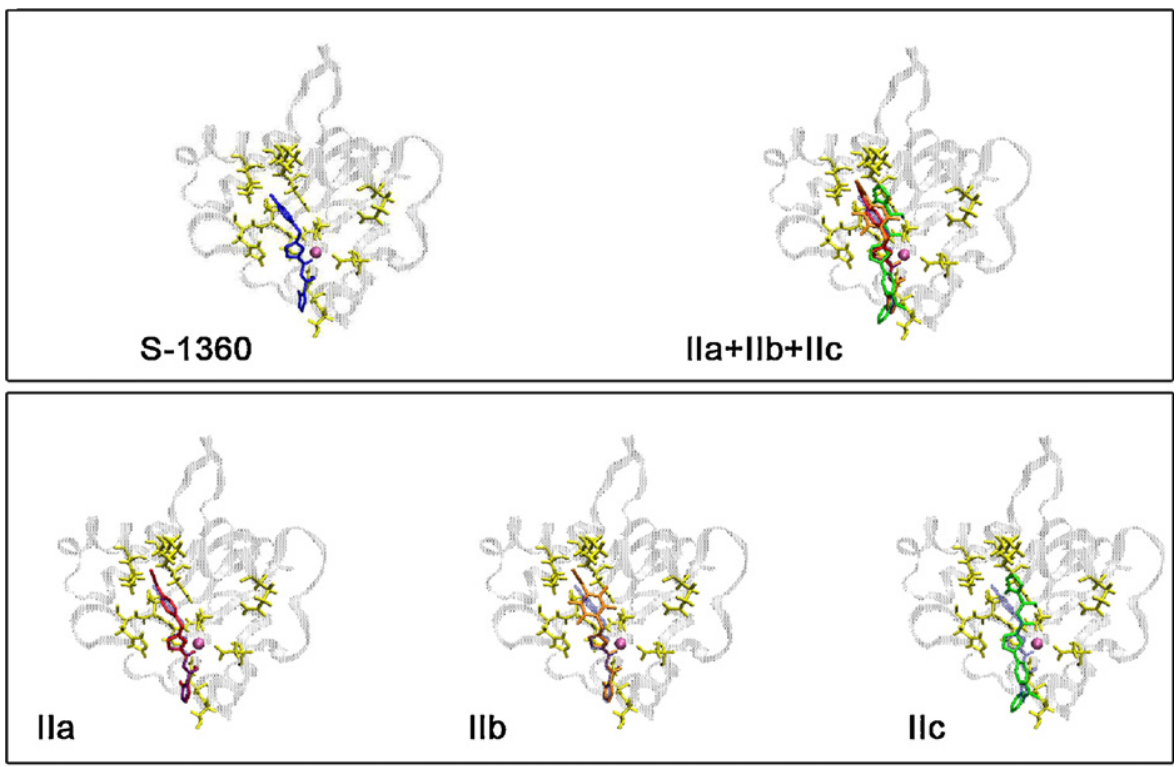

$\mathrm{Mg}^{2+}$ ion is shown in magenta.

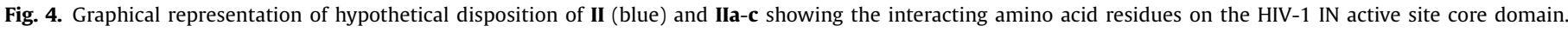

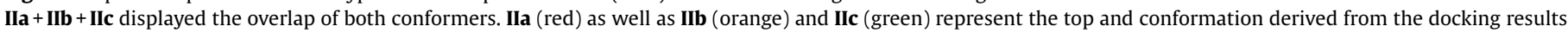
for each monomer (overlapped with II). (For interpretation of the references to colour in this figure legend, the reader is referred to the web version of the article.)

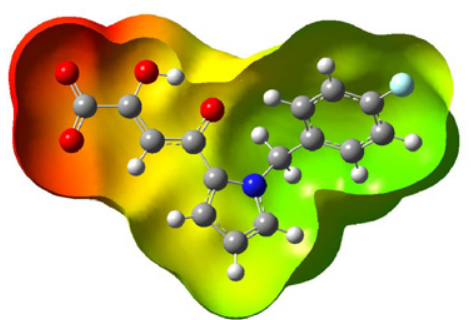

L-731,988 (I)

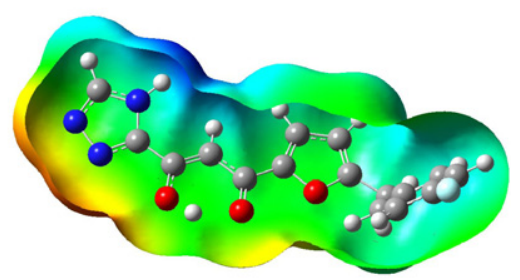

S-1360 (II)

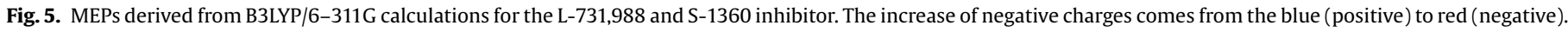
(For interpretation of the references to colour in this figure legend, the reader is referred to the web version of the article.)

Table 2

Inhibition of HIV-1 integrase catalytic activities of title compounds.

\begin{tabular}{lllc}
\hline Compounds & $3^{\prime}$-Processing $\mathrm{IC}_{50}(\mu \mathrm{M})$ & Strand transfer $\mathrm{IC}_{50}(\mu \mathrm{M})$ & SI $^{\mathrm{a}}$ \\
\hline $\mathbf{I}^{\mathrm{b}}$ & $15.2 \pm 2$ & $0.54 \pm 0.08$ & 28 \\
Ia & $12.3 \pm 3.2$ & $0.82 \pm 0.06$ & 15 \\
$\mathbf{I b}$ & $28.3 \pm 4.7$ & $3.57 \pm 0.51$ & 8 \\
$\mathbf{I c}$ & 25 & 3.7 & 6.7 \\
$\mathbf{I I}^{\mathrm{c}}$ & $11 \pm 2$ & $0.6 \pm 0.1$ & 18 \\
\hline
\end{tabular}

a Selectivity index. Values are from average of two or three independent experiments.

b From Sechi et al. (2006).

c From Al-Mawsawi et al. (2007).

charge distributions. In fact, the charges on some key atoms are important both in QSAR studies and in supporting mechanistic hypotheses. Fig. 5 displays the three-dimensional molecular electrostatic potential (MEP) surfaces for L-731,988 and S-1360, which were generated from the BLYP/MM optimized structures. The most nucleophilic regions (negative electronic potential) are shown in red, while the most electrophilic regions (positive electrostatic potential) are shown in blue. A more intense region of negative electrostatic potential around the 2-enol and carboxylate group of L-731,988 was observed. Otherwise, the triazole ring of S-1360 shows a bit of a positive electrostatic potential. These results are in agreement with those expected from the deprotonated and the neutral forms (for L-731,988 and S-1360, respectively). Moreover, these results can further explain the slightly different disposition of these inhibitors within the active site, particularly the interaction with the $\mathrm{Mg}^{2+}$ ion as observed.

\section{Conclusion}

In this study we designed and synthesized three kinds of photoprobes derived from the representative inhibitor L-731,988, and performed a synthetic route for the preparation of the $S$ 1360 photolabeled analogues. Photoprobes Ia-c represent novel photoaffinity ligands, which may provide useful tools for studying enzyme interactions of the DKA inhibitor class of HIV-1 IN inhibitors.

\section{Acknowledgements}

We thank Dr Maria Orecchioni and Mr Paolo Fiori for assistance with NMR spectroscopy. MS is grateful to Fondazione Banco di Sardegna and to Università di Sassari for their partial financial support. The work in NN's laboratory was supported by funds from the Campbell Foundation. 


\section{References}

Al-Mawsawi, L.Q., Fikkert, V., Dayam, R., Witvrouw, M., Burke Jr., T.R., Borchers, C.H., Neamati, N., 2006. Discovery of a small-molecule HIV-1 integrase inhibitorbinding site. Proc. Natl. Acad. Sci. U.S.A. 103, 10080-10085.

Al-Mawsawi, L.Q., Sechi, M., Neamati, N., 2007. Single amino acid substitution in HIV-1 integrase catalytic core causes a dramatic shift in inhibitor selectivity. FEBS Lett. 581, 1151-1156.

Anthony, N.J., 2004. HIV-1 integrase: a target for new AIDS chemotherapeutics. Curr. Top. Med. Chem. 4, 979-990.

Araki, M., Sakata, S., Takei, H., Makuiyama, T., 1974. A convenient method for the preparation of ketones by the reaction of Grignard reagents with carboxylic acid derivatives. Bull. Chem. Soc. Jpn. 47, 1777-1780.

Barbaro, G., Scozzafava, A., Mastrolorenzo, A., Supuran, C.T., 2005. Highly active antiretroviral therapy: current state of the art, new agents and their pharmacological interactions useful for improving therapeutic outcome. Curr. Pharm. Des. 11, 1843-1850.

Barreca, M.L., Lee, K.W., Chimirri, A., Briggs, J.M., 2003. Molecular dynamics studies of the wild-type and double mutant HIV-1 integrase complexed with the 5CITEP inhibitor: mechanism for inhibition and drug resistance. Biophys. J. 84, 1450-1463.

Billich, A., 2003. S-1360. Shionogi-GlaxoSmithKline. Curr. Opin. Invest. Drugs 4, 206-209.

Chang, G., Guida, W.C., Still, W.C., 1989. An internal coordinate Monte Carlo method for searching conformational space. J. Am. Chem. Soc. 111, 4379-4386.

Chehade, K.A.H., Spielmann, H.P., 2000. Facile and efficient synthesis of 4azidotetrafluoroaniline: a new photoaffinty reagent. J. Org. Chem. 65, 49494953.

Chen, I.J., Neamati, N., MacKerell Jr., A.D., 2002. Structure-based inhibitor design targeting HIV-1 integrase. Curr. Drug Targets Infect. Disord. 2, 217-234.

Cohen, J., 2002. Therapies. Confronting the limits of success. Science 296, 2320-2324.

Cotelle, P., 2006. Patented HIV-1 integrase inhibitors (1998-2005). Recent Patents Anti-Infect. Drug Discov. 1, 1-15.

Dayam, R., Neamati, N., 2004. Active site binding modes of the $\beta$-diketoacids: a multiactive site approach in HIV-1 integrase inhibitor design. Bioorg. Med. Chem. 12, 6371-6381.

De Clercq, E., 2002. Strategies in the design of antiviral drugs. Nat. Rev. Drug Discov. $1,13-25$.

De Clercq, E., 2005. New approaches toward anti-HIV chemotherapy. J. Med. Chem. 48, 1297-1313.

Dormán, G., Prestwich, G.D., 1994. Benzophenone photophores in biochemistry. Biochemistry 33, 5661-5673.

Dormán, G., Prestwich, G.D., 2000. Using photolabile ligands in drug discovery and development. Trends Biotechnol. 18, 64-77.

Espeseth, A.S., Felock, P., Wolfe, A., Witmer, M., Grobler, J., Anthony, N., Egbertson, M., Melamed, J.Y., Young, S., Hamill, T., Cole, J.L., Hazuda, D.J., 2000. HIV-1 integrase inhibitors that compete with the target DNA substrate define a unique strand transfer conformation for integrase. Proc. Natl. Acad. Sci. U.S.A. 97, 11244-11249.

Fedan, J.S., Hogaboom, G.K., O’Donnell, J.P., 1984. Photoaffinity labels as pharmacological tools. Biochem. Pharmacol. 33, 1167-1180.

Fleming, S.A., 1995. Chemical reagents in photoaffinity labeling. Tetrahedron 51, 12479-12520.

Gasteiger, J., Marsili, M., 1980. Iterative partial equalization of orbital electronegativity-a rapid access to atomic charges. Tetrahedron 36, 3219-3228.

Gobbi, S., Cavalli, A. Negri, M. Schewe, K.E., Belluti, F., Piazzi, L., Hartmann, R.W. Recanatini, M., Bisi, A., 2007. Imidazolylmethylbenzophenons as highly potent aromatese inhibitors. J. Med. Chem. 50, 3420-3422.

Goldgur, Y., Craigie, R., Cohen, G.H., Fujiwara, T., Yoshinaga, T., Fujishita, T., Sugimoto, H., Endo, T., Murai, H., Davies, D.R., 1999. Structure of the HIV-1 integrase catalytic domain complexed with an inhibitor: a platform for antiviral drug design. Proc. Natl. Acad. Sci. U.S.A. 96, 13040-13043.

Griffin, R.J., 1996. The 4-azidobenzyloxy carbonyl function; application as a novel protecting group and potential prodrug modification for amines. J. Chem. Soc., Perkin Trans. 1, 1205-1211.

Grobler, J.A., Stillmock, K., Hu, B., Witmer, M., Felock, P., Espeseth, A.S., Wolfe, A., Egbertson, M., Bourgeois, M., Melamed, J., Wai, J.S., Young, S., Vacca, J., Hazuda, D.J., 2002. Diketo acid inhibitor mechanism and HIV-1 integrase: implications for metal binding in the active site of phosphotransferase enzymes. Proc. Natl. Acad. Sci. U.S.A. 99, 6661-6666.

Hazuda, D.J., Felock, P., Witmer, M., Wolfe, A., Stillmock, K., Grobler, J.A., Espeseth, A., Gabryelski, L., Schleif, W., Blau, C., Miller, M.D., 2000. Inhibitors of strand transfer that prevent integration and inhibit HIV-1 replication in cells. Science 287, 646-650.

Hatanaka, Y., Sadakane, Y., 2002. Photoaffinity labeling in drug discovery and developments: chemical gateway for entering proteomic frontier. Curr. Top. Med. Chem. 2, 271-288.

Keana, J.F.W., Xiong Cai, S., 1990. New reagents for photoaffinity labeling: synthesis and photolysis of functionalized perfluorophenyl azides. J. Org. Chem. 55, 3640-3647.
Knight, D.W., 1979. Formation and reactivity of bis-anions derived from furoic acids. Tetrahedron Lett. 5, 469-472.

Kotzyba-Hibert, F., Kapfer, I., Goeldner, M., 1995. Recent trends in photoaffinity labeling. Angew. Chem., Int. Ed. Engl. 34, 1296-1312.

Lei, H., Atkinson, J., 2000. Synthesis of phytyl-and-chroman-derivatized photoaffinity labels on $\alpha$-tocopherol. J. Org. Chem. 65, 2560-2567.

Little, S.J., Holte, S., Routy, J.P., Daar, E.S., Markowitz, M., Collier, A.C., Koup, R.A., Mellors, J.W., Connick, E., Conway, B., Kilby, M., Wang, L., Whitcomb, J.M., Hellmann, N.S., Richman, D.D., 2002. Antiretroviral-drug resistance among patients recently infected with HIV. New Engl. J. Med. 347, 385-394.

Morris, G.M., Goodsell, D.S., Halliday, R.S., Huey, R., Hart, W.E., Belew, R.K., Olson, A.J. 1998. Automated docking using a Lamarckian genetic algorithm an empirica binding free energy function. J. Comp. Chem. 19, 1639-1662.

Morris, G.M., Goodsell, D.S., Huey, R., Olson, A., 1996. Distributed automated docking of flexible ligands to proteins: parallel application of AutoDock 2.4. J. Comput Aided Mol. Des. 10, 293-304.

Neamati, N., Marchand, C., Pommier, Y., 2000. HIV-1 integrase inhibitors: past present, and future. Adv. Pharmacol. 49, 147-165.

Neamati, N., 2001. Structure-based HIV-1 integrase inhibitor design: a future perspective. Expert Opin. Investig. Drugs 10, 281-296.

Neamati, N., 2002. Patented small molecule inhibitors of HIV-1 integrase: a ten-year saga. Expert Opin. Ther. Pat. 12, 709-724.

Norcross, R.D., Von Matt, P., Kolb, H.C., Bellŭs, D., 1997. Synthesis of nove cyclobuthylphosphonic acids as inhibitors of imidazole glycerol phosphate dehydratase. Tetrahedron 53, 10289-10312.

Pais, G.C.G., Burke, T.R., 2002. Novel aryl diketo-containing inhibitors of HIV-1 integrase. Drugs Future 27, 1101-1111.

Pommier, Y., Johnson, A.A., Marchand, C., 2005. Integrase inhibitors to treat HIV/AIDS Nat. Rev. Drug Discov. 4, 236-248.

Rowley, M., 2008. The discovery of raltegravir, an integrase inhibitor for the treatment of HIV infection. Prog. Med. Chem. 46, 1-28.

Sechi, M., Derudas, M., Dallocchio, R., Dessì, A., Bacchi, A., Sannia, L., Carta, F., Palomba, M., Ragab, O., Chan, C., Shoemaker, R., Sei, S., Dayam, R., Neamati, N., 2004a. Design and synthesis of novel indole $\beta$-diketo acid derivatives as HIV-integrase inhibitors. J. Med. Chem. 47, 5298-5310.

Sechi, M., Angotzi, G., Dallocchio, R., Dessì, A., Carta, F., Sannia, L., Mariani, A., Fiori, S., Sanchez, T., Movsessian, L., Plasencia, C., Neamati, N., 2004b. Design and synthesis of novel dihydroxyindole-2-carboxylic acids as HIV-1 integrase inhibitors Antiviral Chem. Chemother. 15, 67-81.

Sechi, M., Bacchi, A., Carcelli, M., Compari, C., Duce, E., Fisicaro, E., Rogolino, D., Gates, P., Derudas, M., Al-Mawsawi, L.Q., Neamati, N., 2006. From ligand to complexes: inhibition of human immunodeficiency virus type 1 integrase by $\beta$-diketo acid metal complexes. J. Med. Chem. 49, 4248-4260.

Sechi, M., Carcelli, M., Rogolino, D., Neamati, N., 2009. Role of metals in HIV-1 integrase inhibitor design. In: HIV-1 Integrase: Mechanism of Action and Inhibitor Design, John Wiley \& Sons.

Semenova, E.A., Marchand, C., Pommier, Y., 2008. HIV-1 integrase inhibitors: update and perspectives. Adv. Pharmacol. 56, 199-228.

Smith, M.E., 1921. Friedel and Crafts' reaction. The carbomethoxy-benzoyl chloride with aromatic hydrocarbon and aluminium chloride. J. Am. Chem. Soc. 43 1920-1924

Sotriffer, C.A., Ni, H., McCammon, A.J., 2000a. HIV-1 integrase inhibitor interactions at the active site: prediction of binding modes unaffected by crystal packing. J Am. Chem. Soc. 122, 6136-6137.

Sotriffer, C.A., Ni, H., McCammon, A.J., 2000b. Active site binding modes of HIV-1 integrase inhibitors. J. Med. Chem. 43, 4109-4117.

Stoner, E.J., Cothron, D.A., Balmer, M.K., Roden, B.A., 1995. Benzylation via tandem Grignard reaction. Iodotrimethylsilane (TMSI) mediated reduction. Tetrahedron 51, 11043-11062.

Tanaka, A., Teresawa, T., Hagihara, H., Sakuma, Y., Ishibe, N., Sawada, M., Takasugi, H., Tanaka, H., 1998. Inhibitors of acyl-CoA: cholesterol O-acyltransferase (ACAT). Part 1: Identification and structure-activity relationship of a novel series of substituted N-alkyl-N-biphenylylmethyl-N'-arylureas. Bioorg. Med. Chem. 6, 15-30.

Vanek, T., Velkovà, V., Gut, J., 1984. Preparation of 3- and 3,5-substituted-1,2,4 triazole. Collect. Czech. Chem. Commun. 49, 2492-2495.

Wang, Y., Serradell, N., Bolos, J., Rosa, E., 2007. MK-0518, HIV integrase inhibitor. Drugs Future 32, 118-122.

Woodruf, M., Polya, J.B., 1975. Pyrazolidine-3,5-diones with heterocyclic substituents. IV. Ionization constants. Aust. J. Chem. 28, 1583-11583.

Yoshinaga, T., Sato, A., Fujishita, T., Fujiwara, T., 2002. In vitro activity of a new HIV-1 integrase inhibitor in clinical development. In: Proceedings of the 9 th Conference on Retroviruses and Opportunistic Infections, Seattle, USA

Zeinalipour-Loizidou, E., Nicolaou, C., Nicolaides, A., Kostrikis, L.G., 2007. HIV-1 integrase: from biology to chemotherapeutics. Curr. HIV Res. 5, 365-388.

Zhao, H., Neamati, N., Pommier, Y., Burke, T.R., 1997. Design and synthesis of photoactivatable coumarin-containing HIV-1 integrase inhibitors. Heterocycles 45 2277-2282. 